\title{
ARIZONA BIRD COMMITTEE REPORT, 2015-2017 RECORDS
}

\author{
GARY H. ROSENBERG, P. O. Box 91856, Tucson, Arizona 85752-1856; \\ ghrosenberg@comcast.net
}

DAVID VANDER PLUYM, 2841 McCulloch Blvd. N. \#1, Lake Havasu City, Arizona 86403; dvanpluym@gmail.com

LAURENS HALSEY, 1092 South Dutch John Spring Court, Green Valley, Arizona 85614; desert-harrier@cox.net

ABSTRACT: The Arizona Bird Committee reviewed 287 records and updated the Arizona bird list through 2017, adding eight species: the Common Crane (Grus grus), Lesser Sand-Plover (Charadrius mongolus), Wedge-rumped Storm-Petrel (Oceanodroma tethys), Juan Fernandez Petrel (Pterodroma externa), Wedge-tailed Shearwater (Ardenna pacifica), Pine Flycatcher (Empidonax affinis), California Scrub-Jay (Aphelocoma californica), and Little Bunting (Emberiza pusilla). These bring the Arizona state list to 563 species in good standing.

This is the ninth published report of the Arizona Bird Committee (ABC; Speich and Parker 1973, Speich and Witzeman 1975, Rosenberg and Witzeman 1998, 1999, Rosenberg 2001, Rosenberg et al. 2007, 2011, 2017). This report covers records from the period between 2015 and the end of 2017, and in addition includes some recently reviewed records from prior years. The $\mathrm{ABC}$ reviewed a total of 287 records (some with multiple submissions from several observers), of which 238 (83\%) were accepted. Eight species were added to the Arizona state list, bringing it to 563 species in good standing.

Other highlights in this report include acceptance of Arizona's first physically documented Black Swift (Cypseloides niger), fourth through eighth Ruby-throated Hummingbirds (Archilochus colubris), doubling the previous number of state records, second Royal Tern (Thalasseus maximus), second Black Storm-Petrel (Oceanodroma melania), fourth through eighth Least Storm-Petrels (Oceanodroma microsoma), first nesting of the Rose-throated Becard (Pachyramphus aglaiae) since 2006, second and third Couch's Kingbirds (Tyrannus couchii), first confirmed nesting of the Tufted Flycatcher (Mitrephanes phaeocercus), fifth Yellow-bellied Flycatcher (Empidonax flaviventris), fourth Carolina Wren (Thryothorus ludovicianus), fourth and fifth Blue Mockingbirds (Melanotis caerulescens), second White Wagtail (Motacilla alba), second White-winged Crossbill (Loxia leucoptera), third LeConte's Sparrow (Ammodramus leconteii), and tenth Fan-tailed Warbler (Basileuterus lachrymosa).

The current Arizona Bird Committee (2019) consists of Chris D. Benesh, Andrew Core, Sean Fitzgerald, Lauren Harter (who serves as chair), Scott Olmstead, Gary H. Rosenberg (who also serves as secretary), David Vander Pluym, and Magill Weber. Recent committee members who also voted on records in this report include Laurens Halsey, Eric Hough, Kurt Radamaker (who also serves as web master), Dave Stejskal, and John Yerger. Janet Witzeman serves in a nonvoting capacity as assistant secretary and has done so since the inception of the committee in the early 1970 s. 
The ABC's web site (http://abc.azfo.org) includes the Arizona state list, a list of species currently reviewed, the $\mathrm{ABC}$ 's bylaws, a list of current committee members, a brief history of the $\mathrm{ABC}$, an electronic form for reporting, and all past reports of the $\mathrm{ABC}$ (as published in Western Birds).

The $\mathrm{ABC}$ encourages observers to submit documentation for species on the review list, as well as species new for Arizona. All material should be submitted via the electronic link above or sent to Rosenberg at the address above. The committee would like to emphasize the importance of submitting documentation of sightings directly to the $\mathrm{ABC}$ for review. The posting of reports, including those with written descriptions, on local "listservs" or to www.ebird.org may not be assumed to have been discovered by the $\mathrm{ABC}$ nor be assumed to be intended as documentation of a rarity. The $A B C$ prefers reports submitted directly to the committee or to the regional editor for North American Birds (who forwards the material on review-list species to the secretary of the $\mathrm{ABC}$ ). The $\mathrm{ABC}$ thanks the many observers (300+) who have submitted their documentation of sightings to the Arizona Field Ornithologists (AZFO) and ABC. Each record listed below includes a locality, county (abbreviation: see below), date (span normally as published in North American Birds), and initial observer if known. Additional observers who submitted written reports (as indicated by the symbol †), photographs, video recordings, and sound recordings are also listed. All records are of sight reports unless noted otherwise with a symbol for a photograph, sound recording, or specimen (abbreviation: see below). The ABC's current policy as of 2019 is to review reports of birds recurring in successive years only if the bird has left and then returned. Reports of birds that persist for multiple years without leaving are not reviewed after the initial acceptance. In most cases, the total number of Arizona records for a species includes the number of records accepted by the ABC plus those published in Birds of Arizona (Phillips et al. 1964) or the Annotated Checklist of the Birds of Arizona (Monson and Phillips 1981). The ABC emphasizes that a report listed under "reports not accepted" does not necessarily mean that the members of the $\mathrm{ABC}$ "do not believe" the observer. Rather, the documentation supplied to the committee was insufficiently detailed, or may not have met the rigorous standards established individually and independently by each member of the committee in order for the sighting to be substantiated as a formal historical record. The $\mathrm{ABC}$ endeavors to be fair and objective in its evaluation of all reports.

The ABC's abbreviations for counties in Arizona are APA, Apache; COS, Cochise; COC, Coconino; GIL, Gila; GRA, Graham; GRE, Greenlee; LAP, La Paz; MAR, Maricopa; MOH, Mohave; NAV, Navajo; PIM, Pima; PIN, Pinal; SCR, Santa Cruz; YAV, Yavapai; YUM, Yuma. Other nonstandard abbreviations used within this report include $\dagger$, written description; ph., photograph; s.r., sound recording; v.r., video recording; N. M., national monument; NRA, national recreation area; NWR, national wildlife refuge. If the finder of a bird submitted details he or she is acknowledged first; other observers who submitted details follow alphabetically.

Of the numbers appearing in parentheses $(n, n, n)$ after each species name, the first represents the total number of reports published by Phillips et al. (1964) and Monson and Phillips (1981), provided the species was included 
on the ABC's first checklist compiled in 1972 and the record specifies a date and location. To avoid double counting, a few pre-1972 reports from Monson and Phillips (1981) that were later reviewed and published by the $\mathrm{ABC}$ are not included in the pre-committee total. Additionally, a few post1971 reports from Monson and Phillips (1981) that were not reviewed by the committee may be included in the pre-committee total. The "\#" symbol in this location is used for instances in which the species was not recognized at that time or the species was not on the review list. The second number is the number of reports reviewed and accepted by the Arizona Bird Committee since its inception in 1972, excluding the records accepted in this report. Also, certain species (e. g., Red-eyed Vireo and Bobolink) were on the ABC's original review list in 1972, removed from that list in the 1970s, and then reinstated in the 1990s. Therefore, this second number represents only those records the committee has accepted and does not include reports published while the species was not on the review list. The third number is the number of records of the species published in this report. Adding all three numbers yields the total number of records accepted by the ABC. In the case of the Red-eyed Vireo, for example, $(5,37,6)$ signifies that 5 records were published in Birds of Arizona, 37 records were accepted and published in previous $\mathrm{ABC}$ reports, and 6 additional records are published in this report. All totals reflect the number of reports and not the number of individuals. For example, the report of 200 Least Storm-Petrels at Lake Havasu, MOH, after Tropical Storm Nora on 26 Sep 1997 is treated as one record.

\section{ACCEPTED RECORDS}

FULVOUS WHISTLING-DUCK Dendrocygna bicolor (6, 8, 3). The committee accepted the report of eight individuals at Tres Rios, MAR, 20 Dec 2014 († TC), with one still present on $22 \mathrm{Dec} 2014$, as being different from a single bird near Buckeye, MAR, 20 Dec 2014 ( $\dagger$, ph. SH). A report of a group of 12 in Jan 2015 was not submitted to the committee. A group of five was at the Glendale recharge ponds, MAR, 14 Aug 2017 ( $\dagger$, ph. SH). Formerly a regular visitor to southern Arizona and a breeding summer resident in southern California, this species has declined and is now a casual and irruptive visitor (Monson and Phillips 1981, Hamilton 2008) with most recent reports in winter. Winter 2014/2015 also brought a group of six to interior southern California (https://californiabirds.org/cbrc_book/update.pdf).

BRANT Branta bernicla $(2,14,2)$. Accepted records are of one at the Amado sewage-treatment pond, PIM, 16 Nov 2015 (†, ph. LH; ph. JH) and one at the Glendale recharge ponds, MAR, 25 Nov 2017 ( $\dagger$, ph. MH). Both were of the Black Brant (B. b. nigricans), like all of Arizona's Brant previously identified to subspecies.

TRUMPETER SWAN Cygnus buccinator $(0,5,4)$. Accepted records are of two adults at the Sweetwater Wetlands, PIM, 28 Jan 2015 (†, ph. AC; †, ph. PG, BH, SO); six immatures near Palo Verde, MAR, 19-26 Dec 2015 ( $\dagger$, ph. MH); two adults at Pintail Slough, Havasu NWR, MOH, 13 Feb 2016 (†, ph. JP; †, ph. NW); and an adult near Goodyear, MAR, 7 Jan-13 Feb 2017 (†, ph. JR; $\dagger$, ph. MH). The committee believes the unsubmitted report of an adult $29 \mathrm{~km}$ from Goodyear near Palo Verde during this same interval (but never on the same dates) to represent the same individual.

BLACK SCOTER Melanitta nigra $(0,28,3)$. Accepted records are of one at Lake Pleasant, MAR, 22 Nov 2014 († TC), and two, a female and an immature 
male, there 21 Dec 2014-7 Jan 2015, with the female continuing through 1 Feb 2015 (ph. KR; ph. CR). Several committee members raised the possibility that the bird at Lake Pleasant in November may have been one of the two found there in December. One additional record accepted, of an adult male in the Bill Williams arm of Lake Havasu, LAP/MOH, 11 Dec 2016-2 Jan 2017 (ph. R\&AD; † LHa). This species has become more regular in Arizona during the past decade (see Rosenberg et al. 2017) and elsewhere in the Southwest, including Nevada (Tinsman and Meyers 2019). Although the number of accepted Black Scoter records from Arizona now exceeds 30 , the $\mathrm{ABC}$ continues to evaluate reports.

LEAST GREBE Tachybaptus dominicus $(4,18,3)$. Accepted records are of single individuals at an unspecified golf course in Tucson, PIM, 28 Apr-1 May 2015 (†, ph. AC); at Bog Hole Wildlife Area, SCR, 17-21 Dec 2015 (†, ph. AS); and at Arthur Pack Regional Park in Tucson, PIM, 21-25 Nov 2017 (†, ph. JW; ph. WA; †, ph. AC).

GROOVE-BILLED ANI Crotophaga sulcirostris (3, 23, 2). An older report not previously reviewed was accepted from Wenima Wildlife Area, APA, 1 Aug 2010 (ph. MC). Another Groove-billed Ani was at Veterans Oasis Park, MAR, 16-18 Nov 2016 (†, ph., RD; ph. BH, JR; † ph. BJ). Monson and Phillips (1981) described this species as casual in fall, but the $\mathrm{ABC}$ has reviewed few of the earlier records.

BUFF-COLLARED NIGHTJAR Antrostomus ridgwayi (5, 9, 5). Accepted records include up to five individuals at California Gulch, SCR, 31 Mar-1 Oct 2015 (†, s.r. AC, LHa; ph. CM); up to seven there 18 Apr-10 Sep 2016, including a pair seen copulating ( $\dagger$, ph. LH; † TB); and up to five there 4 Apr-5 Sep 2017, including a fresh juvenile suggesting breeding locally (†TJ; †, ph. AC). Up to two, presumably returning individuals (see Rosenberg et al. 2017), were along Proctor Rd., Madera Canyon, PIM, 19 Apr-27 Jul 2015 (†, s.r. LH; †, ph., s.r., ML). Additionally, one was in Alamo Canyon, Organ Pipe Cactus N.M., PIM, 25 Apr 2015 (†JT); three were along Arivaca Creek, Buenos Aires NWR, SCR, 29 May 2015 (†, s.r. DVP); and one was in Aravaipa Canyon, PIN, 26-29 May 2015 (†DJ), where the species occurred during the 1980s. Presumably the same individual returned 27 Apr-25 May 2016 $(† D J)$. Alamo Canyon represents the westernmost site for the Buff-collared Nightjar in Arizona. Reports have increased in recent years, but the $\mathrm{ABC}$ continues to review them and welcomes submissions.

BLACK SWIFT Cypseloides niger (3, 5, 1). Arizona's first physically documented Black Swift came in the form of juvenile found dead in Phoenix, MAR, 25 Sep 2017 (R\&DC; $\dagger$, ph. TC; Figure 1). The specimen was given to the Arizona Department of Game and Fish, transferred to the University of Arizona, and remains uncatalogued as of this writing (fide TC).

RUBY-THROATED HUMMINGBIRD Archilochus colubris $(0,3,4)$. An adult male was in East Whitetail Canyon, Chiricahua Mountains, COS, 24-27 Sep 2015 ( $\dagger$, ph. RT; $\dagger$, ph., JL); a hatch-year male was banded in Bisbee, COS, 26-28 Oct 2015 (†, ph. SW); an adult male was in Flagstaff, COC, 2-3 Jun 2017 (†, ph. JWi); and a hatch-year male was at the Santa Rita Lodge in Madera Canyon, PIM, 24 Oct 2017 ( $\dagger$, ph. LH). These four accepted records more than doubled Arizona's previous total. The Flagstaff record is the first one accepted for the state outside of fall/winter.

PURPLE GALLINULE Porphyrio martinicus (4, 14, 2). Accepted records are of an immature at Granite Basin Lake, YAV, 17-21 Sep 2015 (ph. CT; ph. BP, ph. DR) and an adult at Sweetwater Wetlands, PIM, 4 Jul-4 Aug 2016 (ph. LH; †, ph. AC). Most Purple Gallinules recorded in Arizona have been found between July and mid-September.

COMMON CRANE Grus grus (0, 0, 1). After much discussion at its 2018 meeting, the $\mathrm{ABC}$ unanimously endorsed one individual that summered at Mormon Lake, 


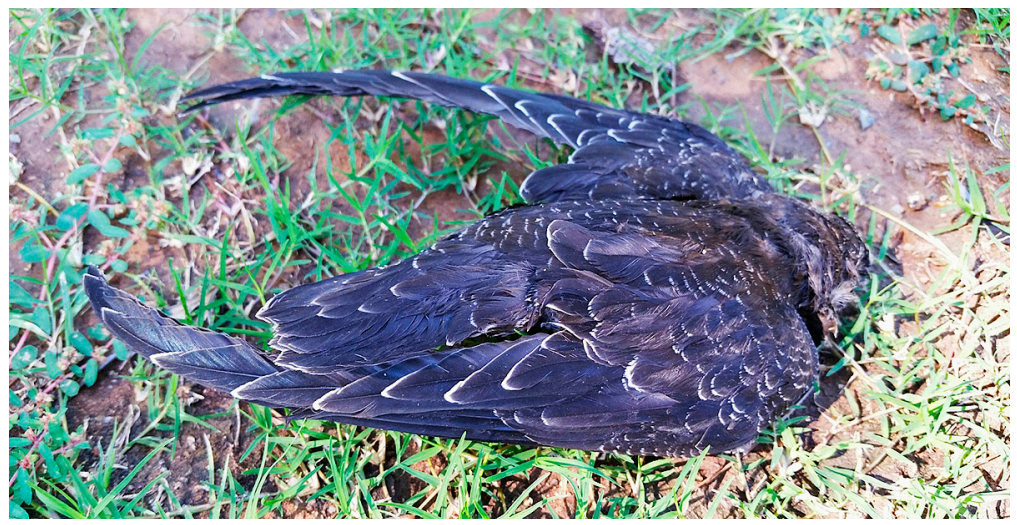

Figure 1. Arizona's first physically documented Black Swift came in the form of a juvenile found dead in Phoenix, Maricopa Co., 25 Sep 2017.

Photo by Troy Corman

COC, 4 May-6 Sep 2017 (ph. DC; †, ph. GHR; ph. SV, DW, MW; Figure 2). Its identification was never in question, but its origin was, as it was the first Common Crane recorded in the lower 48 states in summer (Howell et al. 2014). Mormon Lake is at a lower latitude than typical for summering of eastern Asian populations of the species, but it is resident and breeds at similar latitudes in western Asia (Archibald et

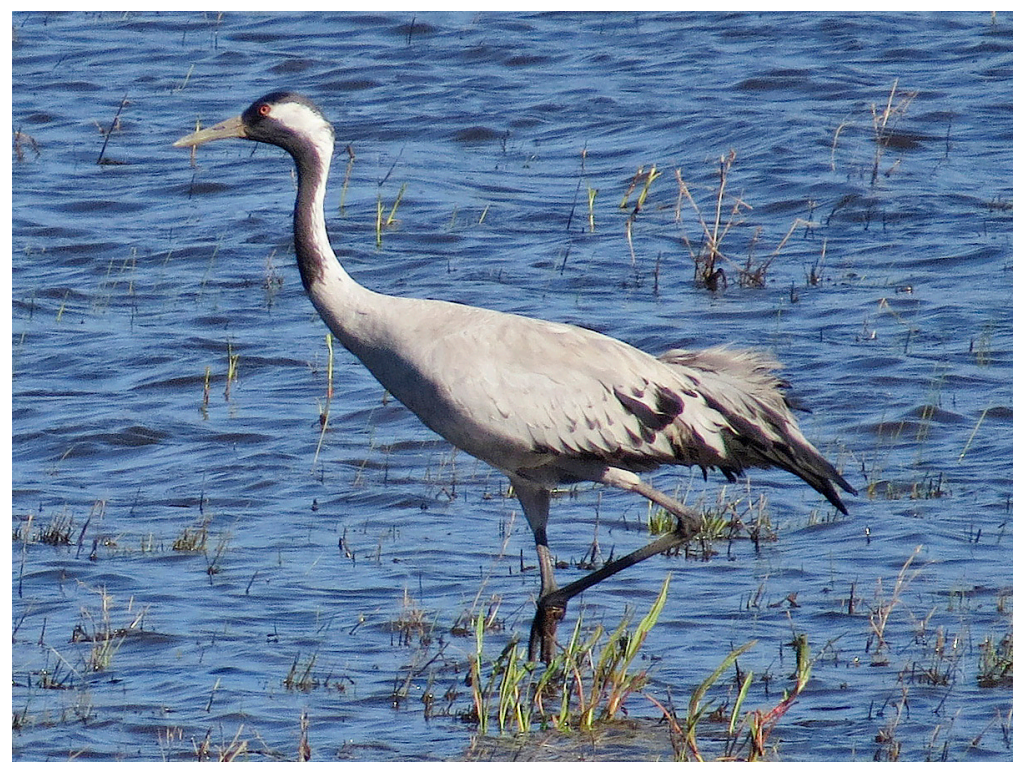

Figure 2. Arizona's first recorded Common Crane was at Mormon Lake, Coconino Co., 4 May-6 Sep 2017.

Photo by Steve Valasek 
al. 2018). Sandhill Cranes (Antigone canadensis) have wandered or summered at lower latitudes away from locations of regular breeding, including in northern Arizona at Luna Lake, APA, and at Mormon Lake (http://azfo.org/gallery/2016/html05/ Sandhill_Crane_MormonLk_Story_03_June_2016.html). The ABC also took into account that no Common Cranes were known to have escaped recently in Arizona and neighboring states, including California (Nelson et al. 2013, Pike et al. 2014), Nevada (Meyers 2015), New Mexico (N. Am. Birds 69:128, 2015), and Utah (www. utahbirds.org/RecCom/2017/2017_18Summary.htm). All of these states have accepted records of the Common Crane, and $\mathrm{ABC}$ members raised the possibility that several of them may represent the same individual.

AMERICAN GOLDEN-PLOVER Pluvialis dominica (21, 28, 7). Accepted records are of one in the Gila River valley near Tres Rios, MAR, 2-5 Apr 2015 ( $\dagger$, ph. LHo; ph. LB, TD); one at Chandler, MAR, 23-28 Nov 2015 (ph. BH, †, ph. TL; ph. JR); one at Willcox, COS, 22-25 Apr 2016 (†, ph. DS; ph. CR); another at Willcox 4-15 Apr 2017 ( $\dagger$, ph. SO); one near Yuma, YUM, 10 Apr 2017 ( $†$, ph. HD); one at Rimmy Jim Tank, COC, 17-22 May 2017 (†, ph. JC, JWi); and one at Gilbert Water Ranch, MAR, 5-12 Nov 2017 (ph. BG). Though the total number of Arizona records now exceeds 50 and the species is considered a rare but regular migrant, the committee continues to review it because of possible confusion with the Pacific Golden-Plover ( $P$. fulva).

LESSER SAND-PLOVER Charadrius mongolus (0, 0, 1). A well-documented juvenile at Round Cedar Lake near Leupp, COC, 2-11 Oct 2016 ( $\dagger$, ph. JWi; ph. TB, GB, RD, GK, TL, CMc, KM, BP, DVP, DW; Figure 3), represented a first state record. From the dusky smudges on the flanks and the uppertail being darker than the back, the bird appears to be C. m. mongolus or C. m. stegmanni (Garner et al. 2003). None of the three subspecies of the C. $m$. atrifrons group is yet known from North America (Howell et al. 2014). Though the Arizona record is only the second for the interior of western North America outside of Alaska, its seasonality matches that of other records of fall juveniles reported along the Pacific coast (Hamilton et al. 2007, Howell et al. 2014).

UPLAND SANDPIPER Bartramia longicauda (3, 8, 2). One was in Franklin, GRE, 9 Jul 2016 (†, ph. AC; ph. DS), a first for Greenlee County, and one was in a colony of reintroduced Black-tailed Prairie Dogs (Cynomys ludovicianus) in Las Cienegas National Conservation Area, PIM, 12 Aug 2017 (†, ph. CDB; ph. CR; †, ph. GHR). Most records in Arizona are from early fall.

HUDSONIAN GODWIT Limosa haemastica $(0,7,1)$. One in Arlington Valley, MAR, 15-28 Jul 2015 ( $†$, ph. KR; †AC) represents the first record accepted for Arizona in fall. All of the state's previous Hudsonian Godwits have been found between 13 and 26 May (Rosenberg et. al. 2017).

RUDDY TURNSTONE Arenaria interpres (2, 8, 3). Accepted records are of an immature at Paloma Ranch, MAR, 19 Aug 2016 (ph. CS); an adult at the Anderson Dairy ponds near Stanfield, PIN, 9 Aug 2017 (†DJ; ph. KK, CR); and of a bird in juvenile plumage at ponds at the Caballero Dairy on the Santa Cruz Flats, PIN, 9 Aug 2017 (†DJ; ph. KK). This species was historically more regular in Arizona during fall migration (see Rosenberg and Witzeman 1998), but there have been few records since it was placed back on the review list in 2002.

RED KNOT Calidris canutus $(2,14,4)$. Accepted records, all of single individuals in juvenile plumage, are from Willcox, COS, 9-13 Sep 2015 (†, ph. TD); Paloma Ranch, MAR, 2 Sep 2016, (ph. CS); the Glendale recharge ponds, MAR, 22-30 Aug 2017 ( $\dagger$, ph. TD); and the Goldman Dairy ponds near Coolidge, PIN, 28 Aug-11 Sep 2017 ( $\dagger$, ph. DJ). This species was encountered in Arizona more regularly in 


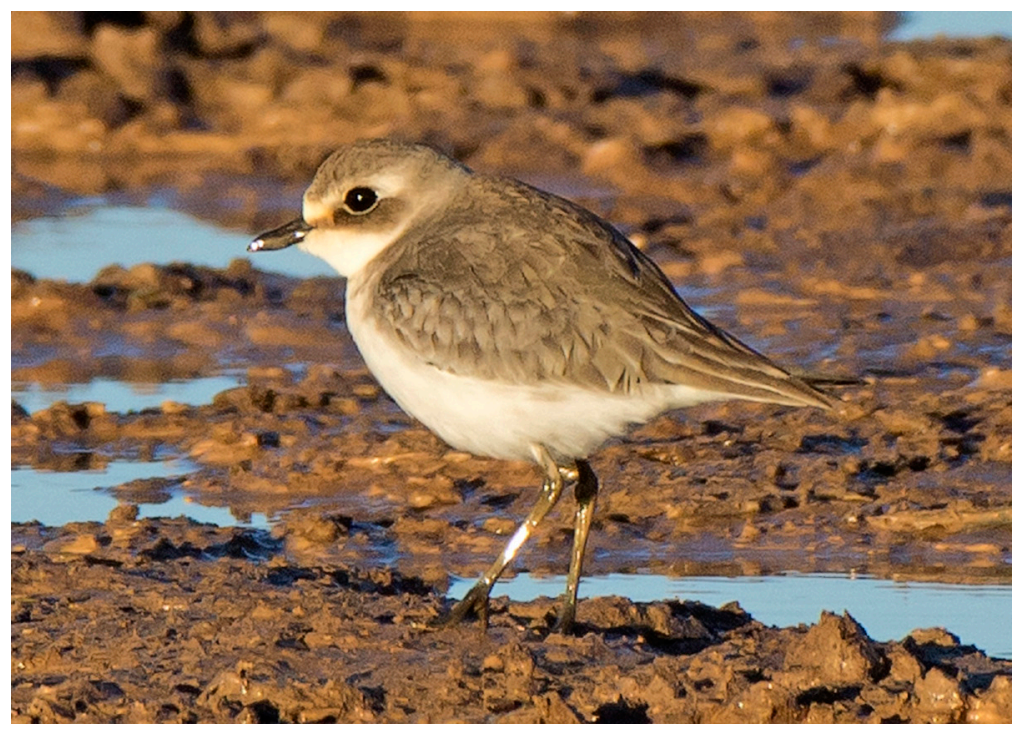

Figure 3. This Lesser Sand-Plover at Round Cedar Lake near Leupp, Coconino Co., 2-11 October 2016 represented a first record for Arizona.

Photo by Gordon Karre

the 1970s and 1980s (see Rosenberg and Witzeman 1998), and the ABC resumed reviewing reports in 2002.

WHITE-RUMPED SANDPIPER Calidris fuscicollis $(0,16,1)$. Three together on a pond on the Santa Cruz Flats, PIN, 13-19 May 2016 ( $\dagger$, ph. GHR) fit the pattern of late spring migrants.

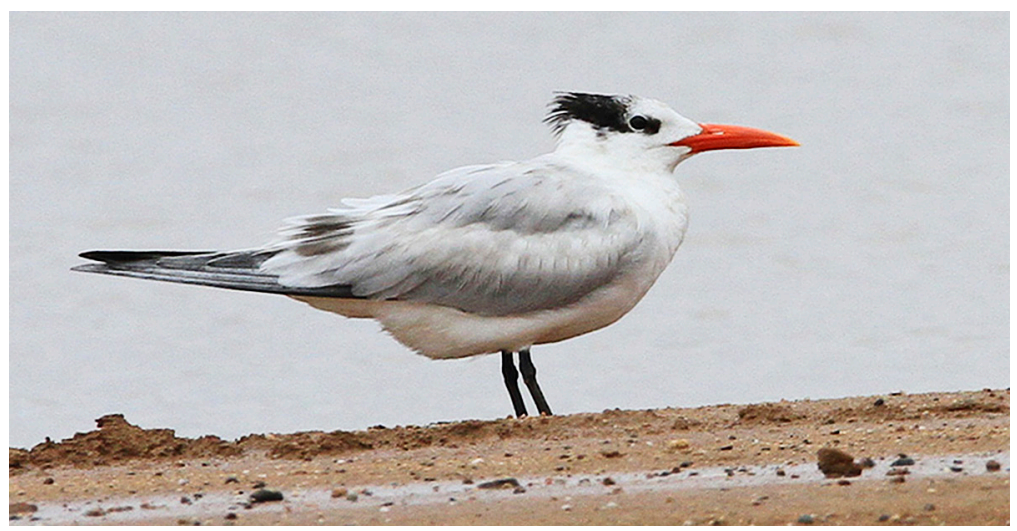

Figure 4. Arizona's second Royal Tern at Sun Lakes near Chandler, Maricopa Co., 23-24 Jul 2017.

Photo by Dale Clark 
POMARINE JAEGER Stercorarius pomarinus $(2,7,1)$. One accepted record of a juvenile discovered at San Carlos Lake, PIN, 14 Nov 2014 (†, ph. KK). The Pomarine is the rarest of the three jaegers in Arizona, with juveniles arriving after late October accounting for most records.

LONG-TAILED JAEGER Stercorarius longicaudus $(0,15,1)$. The committee accepted a report of one adult on Lake Havasu, MOH, 9-12 Sep 2014 (†, ph. DVP).

JAEGER sp. Stercorarius sp. (X, 2, 1). One jaeger, a single individual on Lake Havasu, MOH, 5 Sep 2017 (†DVP), was not submitted at the species level and was reviewed and accepted at the genus level.

BLACK-LEGGED KITTIWAKE Rissa tridactyla (1, 16, 2). Accepted records are of first-cycle birds at Site Six, Lake Havasu City, MOH, 1 Feb 2015 (†, ph. DVP) and 24 Dec 2016-20 Jan 2017 (†, ph. DVP). The one in 2016-2017 was found with a fishing lure in its mouth, but by the end of its stay it had lost the lure.

LAUGHING GULL Leucophaeus atricilla $(1,26,2)$. Accepted records are of one in the Parker Valley near Poston, LAP, 3 Nov 2015 (†, ph. DVP) and another at Lakeside Park in Tucson, PIM, 14 May 2016 ( $\dagger$, ph. BN). Though this species remains primarily a casual visitor to Arizona in spring and summer, it is increasing as a fall visitor. At the 2018 meeting the committee voted to remove the Laughing Gull from the review list, primarily because of its relative ease of identification and the increasing number of records, especially from fall.

MEW GULL Larus canus (0, 24, 2). One in its first cycle was on Lake Havasu, MOH, 6 Jan 2016 ( $\dagger$, ph. DVP); one in its second cycle, likely a spring migrant, was at Rotary Park, Lake Havasu City, MOH, 13 Mar 2017 (†, ph. DVP). Reports of this species have increased in recent years, particularly along the lower Colorado River.

ICELAND GULL Larus glaucoides (3, 10, 5). Single individuals at Mustang Reservoir on the Arizona Strip, MOH, 15 Oct 2014 ( $\dagger$, ph. SL) and at San Carlos Lake, PIN, 8 Nov 2017 (†DJ; ph. KK) provided rare records away from the lower Colorado River valley. The one on 15 Oct was also the earliest recorded in Arizona. More typical reports of single birds came from the lower Colorado River: one that moved between Bullhead City and Katherine Landing on Lake Mohave, Lake Mead NRA, MOH, 11-27 Jan 2016 ( $†$, ph. DVP); one at Site Six on Lake Havasu, MOH, 30 Jan 2016 ( $\dagger$, ph. MH); and one at Rotary Park, Lake Havasu, MOH, 17 Nov 2017 ( $\dagger$, ph. DVP). In 2017 the American Ornithological Society lumped Thayer's (L. thayeri) with the Iceland Gull (L. glaucoides) into a single species (Chesser et al. 2017). All records accepted for Arizona have been of L. g. thayeri in its first cycle.

LESSER BLACK-BACKED GULL Larus fuscus $(0,8,3)$. Accepted records are of an adult at Page, COC, 8 Sep 2016 ( $\dagger$, ph. LP); an adult at the Glendale recharge ponds, MAR, $(\dagger$, ph. JRi); and a first-cycle individual also there, 29-30 Oct 2017 (ph. SB, SH). The frequency of records of species in the western U.S. has increased greatly during the last decade; the first Arizona record was in 2006 (Rosenberg et al. 2011). The California Bird Records Committee discontinued reviewing reports in 2013 (www.californiabirds.org/cbrc_book/update.pdf).

GLAUCOUS-WINGED GULL Larus glaucescens $(1,6,1)$. One accepted record, of a first-winter bird at Katherine Landing, Lake Mohave, Lake Mead NRA, MOH, 18 Jan 2015 ( $\dagger$, ph. DVP; ph. BS). Though five of the previous seven Arizona records were from the lower Colorado River, this is the first record accepted from there since 1981.

ROYAL TERN Thalasseus maximus $(0,1,1)$. The second accepted for Arizona was one in its second cycle at Sun Lakes, MAR, 23-24 Jul 2017 (†, ph. DC; †, ph. AC, LH, GHR; Figure 4). This species is casual inland in the Southwest with five 
records from the Salton Sink (all in summer; Patten et al. 2003) and one in fall from New Mexico (N. Am. Birds 58:118, 174, 2004).

ELEGANT TERN Thalasseus elegans $(0,15,2)$. Accepted records are of an adult in Tucson, PIM, 9-11 Jun 2015 ( $\dagger$, ph. CR; ph. DB, DBr, MMS, CTh) and an immature (first or second cycle) at Mittry Lake, YUM, 9 Aug 2016 ( $\dagger$, ph. HD; ph. MM). The record for Tucson, though accepted unanimously on the first round, generated some discussion as to the possibility of a hybrid with the Sandwich Tern (T. sandvicensis), as the bird's bill showed dusky at the base of the culmen. The Sandwich Tern has occurred in the Elegant Tern's main colony at Isla Rasa in the Gulf of California (Velarde and Rojo 2012), where hybridization is possible, but the committee believed the bill pattern seen at Tucson is likely within the range of variation in the Elegant (see Shoch and Howell 2013). All of Arizona's previous Elegant Terns have been found between mid May and late July; the Mittry Lake record is the state's first for August. Records from the Salton Sink extend from late April to the end of August (Patten et al. 2003).

BLACK SKIMMER Rynchops niger $(0,10,1)$. One accepted record, of two birds at the ponds along Lower River Road 2 km nw. of Palo Verde, MAR, 15 Jul 2016 (ph. DM; †, ph. CF).

RED-THROATED LOON Gavia stellata $(3,23,1)$. One was on Lake Havasu, $\mathrm{MOH}, 7 \mathrm{Dec} 2014$ ( $\dagger$, DVP; ph. LH). The ABC removed the Red-throated Loon from its review list at the end of 2014, as the species has become regular in Arizona, primarily on lakes along the lower Colorado River.

YELLOW-BILLED LOON Gavia adamsii (0, 7, 2). Amazingly, two immature birds were only about $2 \mathrm{~km}$ apart on Lake Mohave within the Lake Mead NRA, at Katherine Landing, MOH, 11 Jan-15 Feb 2016 ( $\dagger$, ph. DVP; ph. BS) and Davis Dam, MOH, 17 Jan-20 Feb 2016 (†, ph. DVP, ph. BS).

WEDGE-RUMPED STORM-PETREL Oceanodroma tethys (0, 0, 7). Searches for displaced seabirds after the remnants of Hurricane Newton passed into southern Arizona resulted in the exciting discovery of multiple individuals of this species at widespread locations. Four were at Lake Patagonia State Park, SCR, 7 Sep 2016 (†, ph., CMc; ph. MB); four more were at the Amado sewage-treatment pond, PIM, 7 Sep 2016 (ph. LH, LPr, CR, BL); and one was found on the ground below lights at the Canoa Ranch Rest Area, PIM, 7 Sep 2016 (†, ph., DVP; †, ph., LHa). Another was found dead a day after the storm in a backyard in Rio Rico, SCR, 8 Sep 2016 (ph. MJ). Also found a day after the storm was a individual grounded but alive near Eloy, PIN, 8 Sep 2016 (ph. VM); one at the Benson sewage-treatment ponds, COS, 8 Sep 2016 ( $\dagger$, ph. LN); and one in Mesa, MAR, 8 Sep 2016 (ph. JMc, BB, CF, $\mathrm{GK} ; \dagger$, ph., LHa; see this issue's front cover). The birds found at Canoa Ranch and Eloy were taken to a rehabilitation facility but did not survive. The specimens (as well as that from Rio Rico) were given to the Arizona Department of Game and Fish, transferred to the University of Arizona, and remain uncatalogued as of this writing (fide TC). This species occurs regularly off the southern tip of the Baja California Peninsula and into the Gulf of California (Howell 2012). Although California has 13 accepted records, all are coastal or pelagic (www.californiabirds.org/cbrc_book/ update.pdf). Measurements of the Arizona specimens identify them as O. t. kelsalli, which breeds in Peru. California's two specimens, as well as two individuals captured and released on Southeast Farallon Island, have been also referred to this subspecies (Kammerichs-Berke 2018). More information on these storm-related records and Hurricane Newton can be found under the appropriate species at http://azfo.org/ gallery/1main/photos_tax.html and https://ebird.org/news/newtonarizona.

BLACK STORM-PETREL Oceanodroma melania (0, 1, 1). Arizona's second 
Black Storm-Petrel was found three days after the remains of Hurricane Newton had passed through the state at the Benson sewage-treatment ponds, COS, 10 Sep 2016 (†, ph. BS, CR; ph. PB, JMe, LH, AR; Figure 5). Arizona's first record was of a flock of at least 40 individuals on Lake Havasu, MOH, 26-30 Sep 1997 after Tropical Storm Nora (Jones 1999, Rosenberg 2001). See the Wedge-rumped Storm-Petrel account for more information on Hurricane Newton.

LEAST STORM-PETREL Oceanodroma microsoma $(0,3,3)$. The ABC accepted three records associated with Hurricane Newton on 7 Sep 2016: one at the Amado sewage-treatment ponds, PIM (ph. LH, BL; †, ph. CR); one at Lake Patagonia State Park, SCR, ( $\dagger$, ph. CMc); and one seen hit by a vehicle (specimen retained) in east Tucson, PIM, ( $\dagger$, ph. BGi). The specimen was given to the Arizona Department of Game and Fish, transferred to the University of Arizona, and remains uncatalogued as of this writing (fide TC). See the Wedge-rumped Storm-Petrel section for more information on Hurricane Newton. This species has previously been brought to the desert Southwest, twice in large numbers, by the remnants of hurricanes (Rosenberg 2001, Patten et. al. 2003).

JUAN FERNANDEZ PETREL Pterodroma externa $(0,0,1)$. A remarkable find related to Hurricane Newton was of one that flew quickly over a yard in Tucson, PIM, 7 Sep 2016 (†, ph. BGi; Figure 6). This represents the first record for Arizona and first fully documented record for the continental United States. Oregon has accepted a sight report (https://oregonbirding.org/wp-content/uploads/2019/01/recordsjan2019. pdf). This species occurs regularly far off of southern Baja California in late summer and early fall (Howell 2012), and there is a prior hurricane-related report from the Gulf of California (Erickson et al. 2006). See the Wedge-rumped Storm-Petrel account for more information on Hurricane Newton.

WEDGE-TAILED SHEARWATER Ardenna pacifica $(0,0,1)$. Representing a first record for Arizona, a light-morph individual was found during Hurricane New-

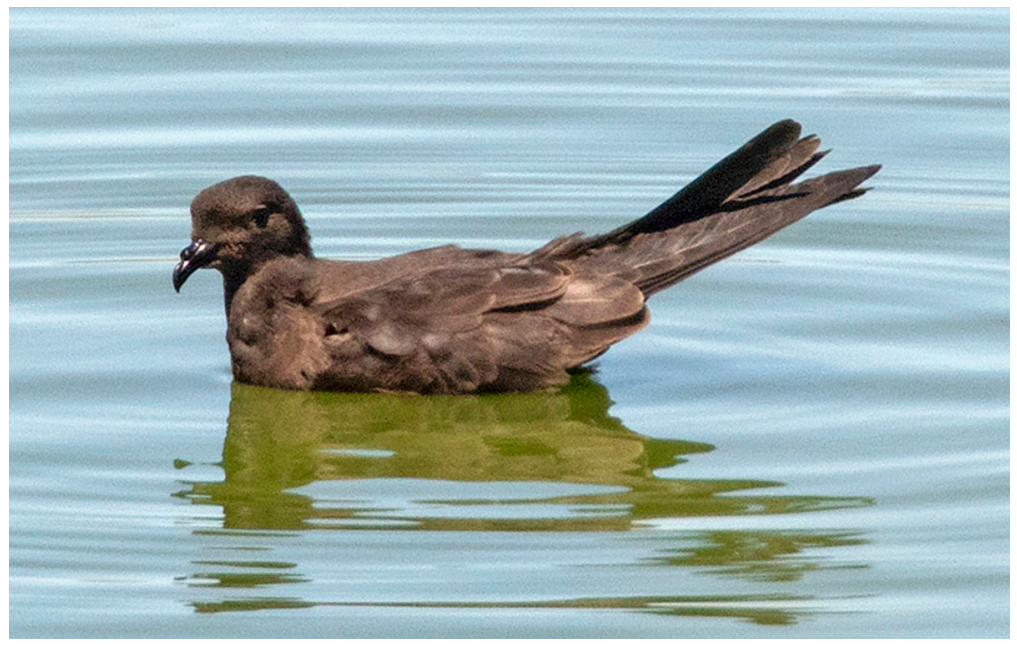

Figure 5. Arizona's second Black Storm-Petrel at Benson, Cochise Co., on 10 Sep 2016, three days after the remains of Hurricane Newton passed through the southern portion of the state. 


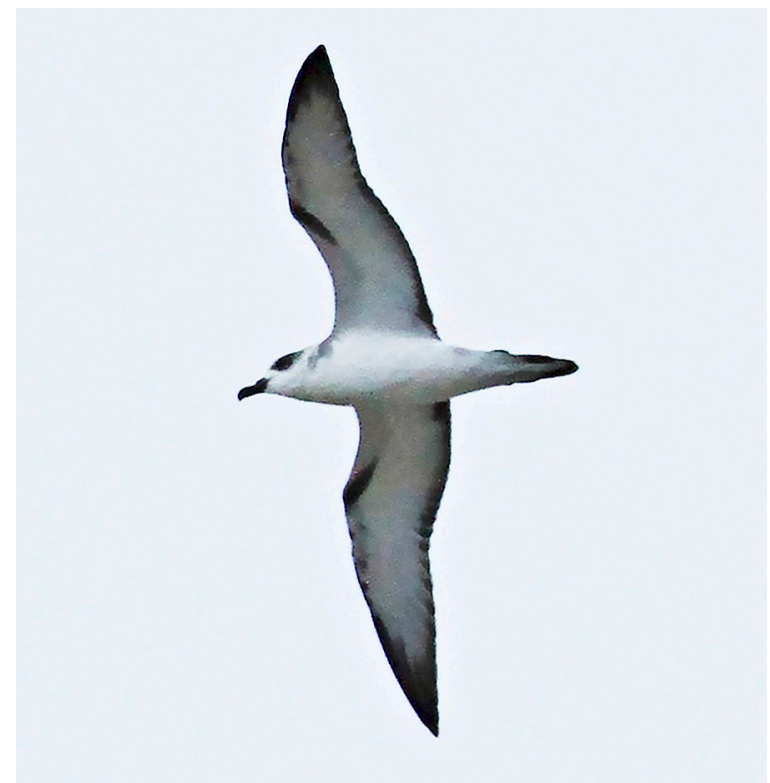

Figure 6. The most remarkable find after the remains of Hurricane Newton passed through Arizona was this Juan Fernandez Petrel that flew over a yard in Tucson on 7 Sep 2016, establishing not only a first state record but a first photographically documented record for the mainland of the United States.

Photo by Brian Gibbons

ton at the Amado sewage-treatment pond, PIM, 7 Sep 2016 (†, ph. LH; Figure 7). This species is regular around the southern tip of the Baja California Peninsula, and California has 10 accepted records, including one from the Salton Sea unrelated to a storm (www.californiabirds.org/cbrc_book/update.pdf; Patten et al. 2003). See the Wedge-rumped Storm-Petrel account for more information on Hurricane Newton.

MAGNIFICENT FRIGATEBIRD Fregata magnificens (4, 10, 1). Two were seen flying together over the Okie Hills within the Barry M. Goldwater Air Force Range, MAR, 19 Jul 2012 ( $\dagger$, ph. JV). A single briefly described frigatebird over the visitor center at Cabeza Prieta NWR, PIM, 22 Oct 2013 (†JV) was accepted at the level of the genus only. Though only the Magnificent Frigatebird has been confirmed in Arizona, the possibility of the Great Frigatebird (F. minor) reaching Arizona was raised by Monson and Phillips (1981). Both the Lesser (F. ariel) and Great Frigatebirds have been recorded in California, as well as the interior West (Sullivan et al. 2007, Howell et al. 2014), so the ABC takes a conservative stance on acceptance at the species level.

WHITE IBIS Eudocimus albus $(2,8,2)$. Accepted records were of a briefly described adult at Alamo Lake, LAP, 5 May 2017 (†CSz), likely the same individual flying past the headquarters of Bill Williams River NWR, LAP, 8 May 2017 (†GKl), and an immature at Sweetwater Wetlands Tucson, PIM, 5 Jul 2017 (ph. DW). 2017 was a good year for the White Ibis in the interior West with accepted records of adults from northern Utah in June (www.utahbirds.org/RecCom/2017/2017_41Summary.htm), and from southern Nevada in August (Tinsman and Meyers 2019). 


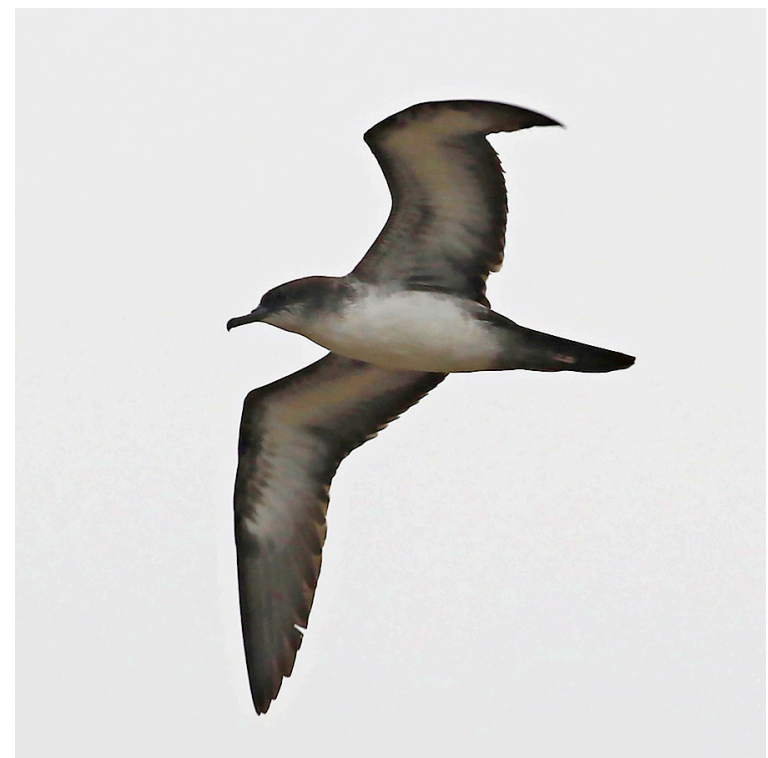

Figure 7. Another first for Arizona associated with Hurricane Newton was this lightmorph Wedge-tailed Shearwater found at the sewage-treatment pond in Pima Co. just north of Amado, Santa Cruz Co., on 7 Sep 2016.

Photo by Laurens Halsey

GLOSSY IBIS Plegadis falcinellus $(0,18,1)$. The single accepted record is of an adult at Willcox, COS, 12 Apr 2016 (†, ph. DS).

SHORT-TAILED HAWK Buteo brachyurus $(0,40,11)$. Accepted records are of one at Tubac, SCR, 8 Mar 2015 (ph. NH); one along Cienega Creek, PIM, 20 Mar 2015 (ph. PS); one in lower Florida Canyon, PIM, 23 Apr 2015 (ph. TH), and seen again in nearby lower Madera Canyon, PIM, 5 May 2015 (ph. LH); one at Summerhaven, Mount Lemmon, PIM, 3 Jun 2015 (†JHi); one in Sierra Vista, COS, 5 Mar 2016 (†JB); one on Mount Lemmon, PIM, 15 May 2016 (ph. BS); one in Hunter Canyon, Huachuca Mts., COS, 5 Aug 2016 (LBe; †RT); one on Aztec Peak, Pinal Mts., PIN, 13 May 2017 (GL; ph. JWe); one juvenile of the dark morph along Paige Creek near Cascabel, PIM, 5 Jun 2017 (ph. KK); one in Carr Canyon, COS, 29 Jul 2017 (ph. EH); and one on Mount Lemmon, PIM, 27 Aug 2017 (MMS; ph. CMc). Although it is difficult to determine whether some individuals are birds returning in successive years, records of the Short-tailed Hawk in Arizona have increased greatly in recent years. Migrants are now being recorded at the hawk watch along the Santa Cruz River near Tubac, and additional records come from a growing number of mountain ranges in southeastern Arizona, north to the Pinal Mountains. Given that there are now more than 50 reports from the state, the $\mathrm{ABC}$ removed this species from its review list at the end of 2017.

RED-HEADED WOODPECKER Melanerpes erythrocephalus (3, 4, 1). The committee agreed that one near Sonoita, PIM, 8 May 2016 (†, ph. KC) was the same as one along Cave Creek, Santa Rita Mountains, SCR, 11 May-11 Jun 2016 ( $\dagger$, ph. AC; ph. CDB; $\dagger$, ph. GHR). The sightings were three days and over $15 \mathrm{~km}$ 
apart, but the species' scarcity in Arizona (first record since 1998) and geographic proximity (reports within the same drainage basin) led the $\mathrm{ABC}$ to conclude that the reports likely represent the same individual.

ROSE-THROATED BECARD Pachyramphus aglaiae (\#, 3, 6). Single males were discovered at Chiricahua N.M., COS, 20 Jan 2015 (ph. PS); in East Whitetail Canyon, Chiricahua Mts., COS, 15 Jul 2015 (†RT); at Cluff Ranch, w. of Safford, GRA, 24 Mar-10 Apr 2016 ( $\dagger$, ph. PS; ph. GK, BG, GJ); and along the De Anza Trail near Tubac, SCR, 3-21 Jan 2017 (ph. KM). A pair was along the Santa Cruz River near Tumacacori, SCR, 10 Jan-6 Feb 2017 (ph. PS), then found nesting on 23 May 2017 (ph. JD) and reported through 12 Sep 2017. This represents the first confirmed nesting in Arizona since 2006 (Rosenberg et al. 2011).

NUTTING'S FLYCATCHER Myiarchus nuttingi $(1,6,1)$. Accepted records of presumed continuing birds in the Bill Williams River NWR are of one near "Honeycomb Bend," $2 \mathrm{~km}$ w. of Planet Ranch, LAP, 8-17 Jun 2015 (†, s.r. EHo); up to two at "Sandy Wash," MOH/LAP, where they bred in 2013, through 25 Nov 2015 (†, s.r. ML, †, s.r., ph. EHo); and one near "Cougar Pt.," LAP, through 24 Jul 2016 (†, s.r. EHo) (see Rosenberg et. al. 2017). At new locations within the Bill Williams River NWR were one at Planet Ranch, MOH, 11 Jun 2015 (†, s.r., ph. EHo), one likely different individual on the north side of the river near "Cougar Pt.," MOH, 22 Jun 2015 (†, s.r. EHo), and one near "Cave Wash," LAP, 10 Aug 2015 (†, s.r., ph. EHo). It is unknown if these represent dispersing young, shifts in the home ranges of previously known adults, or new individuals. The Bill Williams River has suffered from drought in recent years, and reports of Nutting's Flycatchers have shifted toward areas that still have water. Away from the Bill Williams River NWR, one was in California Gulch, SCR, 2-29 Jan 2017 (†, ph. DS; ph. CMc).

COUCH'S KINGBIRD Tyrannus couchii $(0,1,2)$. One was calling at the Texas Canyon Rest Area along Interstate 10 w. of Willcox, COS, 23-25 Jan 2015 (†BZ; †, ph. LH), and another was at Fort Lowell Park, Tucson, PIM, 11 Nov-21 Dec 2017 (ph. MW; †, ph. CR, SO; Figure 8). Arizona's only previous Couch's Kingbird wintered at Tacna, YUM, 11 Jan-7 Mar 2007 (Rosenberg et al. 2011).

TUFTED FLYCATCHER Mitrephanes phaeocercus (0, 3, 2). A single Tufted Flycatcher photographed in Miller Canyon, COS, 26 Apr 2015 (ph. CTr) was followed by another (or the same) in upper Ramsey Canyon, COS, 22 May 2015 (MP; ph. $\mathrm{BBe}, \mathrm{CM}, \mathrm{MBa}, \mathrm{MMe}$ ). In upper Ramsey Canyon, one individual with a nest was located 7 Jun 2015 (ph. DG, DW, WB), and two birds were present after 11 Jun 2015. In 2016, a single individual was discovered along the Bledsoe Loop in lower Ramsey Canyon 28 Mar 2016 (ph. LD), and one found near the previous year's nest in upper Ramsey Canyon on 16 Apr 2016 was photographed on 4 May 2016 (ph. TJ). Three individuals (pair plus one juvenile) were there 24 Jul 2016 (ph. CDB) and last reported 29 Oct 2016. In 2017, one was again along the Bledsoe Loop in lower Ramsey Canyon on 12 Mar 2017 (ph. CMc); one or two were at the Reef Townsite in Carr Canyon, COS, from 20 Mar to 11 Aug 2017 (OB; ph. TBa, CDB, KM, MC); and a pair was at the previous territory in upper Ramsey Canyon 10 Mar-25 Jul 2017 (TLa; www.eBird.org). Figuring out the number of unique records is difficult. Clearly, a pair nested successfully in upper Ramsey Canyon each year from 2015 to 2017. What is unclear is if the "early" records from lower Ramsey Canyon, and the record for Carr Canyon represent young dispersing from the nest or new individuals. Thus the number of unique records is approximate.

YELLOW-BELLIED FLYCATCHER Empidonax flaviventris $(1,3,1)$. One was at Sonoita, SCR, 16 Sep 2016 (ph. KC). Two of Arizona's previous four Yellow-bellied Flycatchers were also discovered in mid-September. 


\section{ARIZONA BIRD COMMITTEE REPORT, 2015-2017 RECORDS}

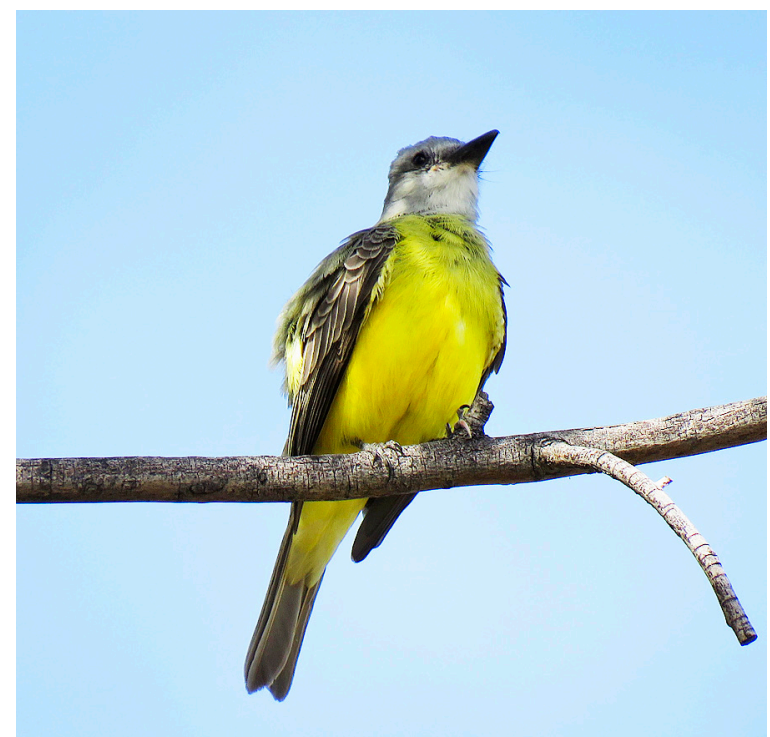

Figure 8. Arizona's third Couch's Kingbird at Tucson, Pima Co., 11 Nov-21 Dec 2017.

Photo by Melissa Williams

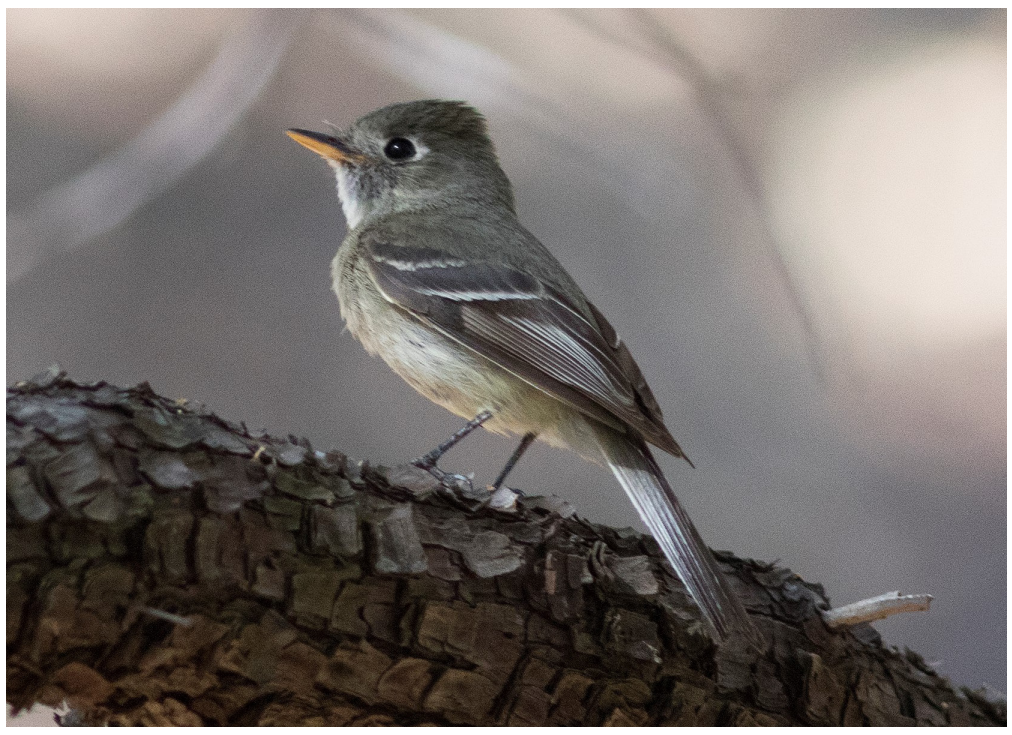

Figure 9. Arizona's and the United States' first Pine Flycatcher at Aliso Spring on the east side of the Santa Rita Mountains, Pima Co., 28 May-7 Jul 2016.

Photo by Gary H. Rosenberg 


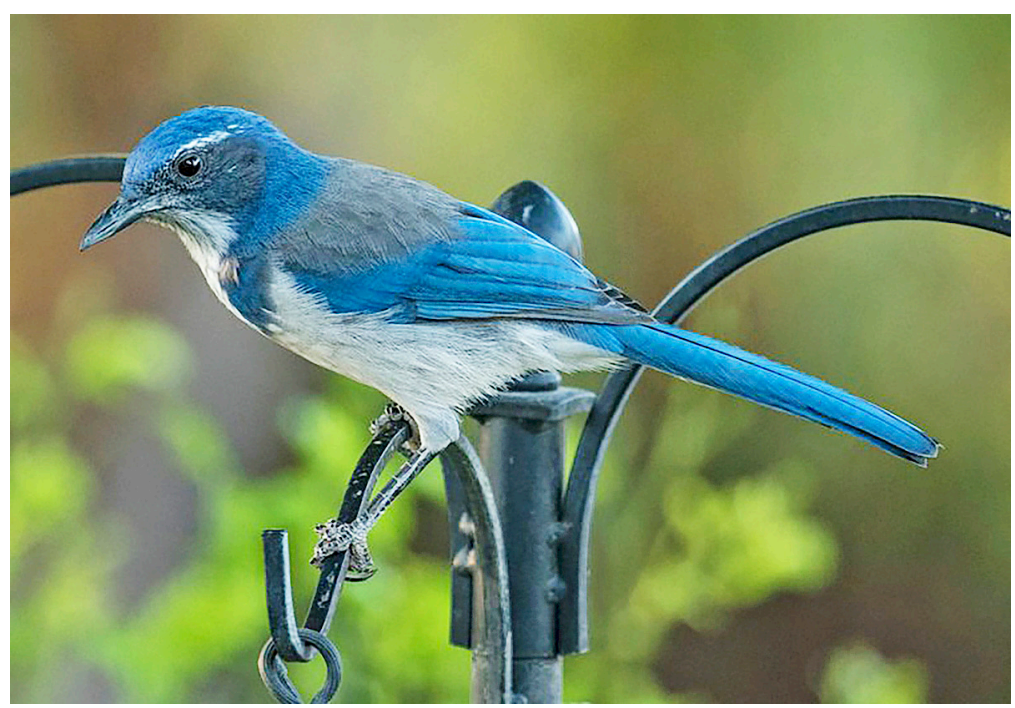

Figure 10. This California Scrub-Jay was seen intermittently at Yuma, Yuma Co., 22 Aug 2016-16 May 2017, establishing a first Arizona record.

Photo by Mike Margolis

LEAST FLYCATCHER Empidonax minimus $(3,7,1)$. One was along Sonoita Creek, SCR, 23 Jan 2015 ( $†$, ph., SM).

PINE FLYCATCHER Empidonax affinis (0, 0, 1). Arizona's and the United States' first record was established by an apparent female at Aliso Spring on the east side of the Santa Rita Mountains, PIM, 28 May-7 Jul 2016 (†, ph., s.r. DS; †, ph., s.r. GHR; ph. LH; see Rosenberg and Stejskal 2018; Figure 9). It constructed and was observed sitting in a nest that apparently never held eggs, and it was never heard singing, only calling.

PHILADELPHIA VIREO Vireo philadelphicus (5, 15, 2). Accepted records are of one along Paige Creek on the east side of the Rincon Mts., PIM, 17 Oct 2016 (ph. PS) and one near Meteor Crater, COC, 24 Sep 2017 (ph. JWi). This species remains a casual visitor to Arizona, with most records from late fall.

RED-EYED VIREO Vireo olivaceus $(5,37,6)$. Accepted records are of one at Cameron, COC, 17 May 2015 (ph. CBa); one in Picture Canyon, COC, 12 Sep 2015 (ph. CG); one at Box Bar Recreation Area along the lower Verde River, MAR, 6 Oct 2015 ( $\dagger$, ph. TD); one banded at Leslie Canyon NWR, COS, 14 Jun 2016 (ph. LN); one in Miller Canyon, COS, 8-15 Aug 2017 († JWo); and one at Gilbert Water Ranch, MAR, 29 Oct-4 Nov 2017 (CS; ph. DC). This species has become a rare but regular migrant in Arizona.

YELLOW-GREEN VIREO Vireo flavoviridis $(1,11,2)$. One male was very well documented along the Santa Cruz River near Tumacacori, SCR, 8 Aug 2017 ( $\dagger$, ph., s.r., CDB), and another was seen and recorded singing at Las Cienegas National Conservation Area, PIM, 17 Sep 2017 (s.r. JMb). Virtually all of Arizona's records are for summer, the one for September being the latest. 
CALIFORNIA SCRUB-JAY Aphelocoma californica $(0,0,1)$. One was discovered in a residential yard in Yuma, YUM, 22 Aug 2016 and seen intermittently to 16 May 2017 (ph. MK; ph. MMa. CMc, DVP, LH; Figure 10). The committee decided to accept this record on the basis of the understanding that this species, while mostly sedentary, has wandered at this season to the Salton Sink (twice, Patten et al. 2003, N. Am. Birds 60:141, 2012), to the western edge of the Mojave Desert downslope from breeding areas to the west, and to Idaho and Montana. The breeding birds closest to Yuma are about $135 \mathrm{~km}$ to the west in the Jacumba Mountains along the border between San Diego and Imperial counties, California (Unitt 1984).

CAVE SWALLOW Petrochelidon fulva $(0,9,1)$. One photographed on the Santa Cruz Flats, PIN, 3 Sep 2017 (ph. CTr) represents only the tenth record for Arizona.

BLACK-CAPPED CHICKADEE Poecile atricapillus $(4,8,1)$. Two individuals were found in Colorado City, MOH, 14 Jan-9 Mar 2017 (ph. CMc; ph. DVP). This species is a casual winter visitor in northwestern Arizona and had not been found at this location since the winter of 2009-2010 (Rosenberg et al. 2011). It breeds just to the north along the Virgin River in extreme southwestern Utah.

CAROLINA WREN Thryothorus ludovicianus $(0,3,1)$. Arizona's fourth recorded Carolina Wren came to a feeder in Overgaard, NAV, 14 Dec 2015-18 Jan 2016 (ph. JJ; ph. EH).

SINALOA WREN Thryophilus sinaloa $(0,4,0)$. After wintering in Huachuca Canyon, COS, during 2013-2014, and again 2014-2015 (see Rosenberg et al. 2017), a Sinaloa Wren was discovered again at this location 20 Aug 2015-6 May 2016 (ph. BM; ph. JVR, RG, CR, MC); the ABC considers it a returning individual. The location is the same as Arizona's second record of this species in 2009.

WOOD THRUSH Hylocichla mustelina $(0,18,2)$. Accepted records are of one at Meteor Crater, $60 \mathrm{~km}$ e. of Flagstaff, COC, 13-14 Oct 2016 (CL; ph. TLi, JCr) and one at Dateland, YUM, 29 Oct-4 Nov 2017 (ph. MV). This species remains a casual visitor to Arizona, mainly in fall.

AZTEC THRUSH Ridgwayia pinicola $(0,25,2)$. Two accepted records: one at Madera Canyon, SCR, 30 May-2 Jun 2016 (ph. GJ), and one at Aliso Spring, e. side of the Santa Rita Mts., PIM, 12-13 Jun 2016 (ph. JG). Most of the Arizona records are from late summer (Jul-Sep), but there are a handful of May and June records, including Arizona's first, of a bird discovered in Huachuca Canyon 30 May 1978 (Rosenberg and Witzeman 1999).

BLUE MOCKINGBIRD Melanotis caerulescens (0, 3, 2). One was photographed in Ramsey Canyon, COS, 21 May 2015 (ph. MR), and another was netted and banded at Cook's Lake along the lower San Pedro River, PIN, 11 Jul 2015 (ph. WL). Arizona's three previous records are for winter.

WHITE WAGTAIL Motacilla alba $(0,1,1)$. Arizona's second White Wagtail was at Ajo, PIM, 29 Mar-1 Apr 2017 (ph. DB; ph. LH, JY, CVC, TH, CMc; Figure 11). According to Peter Pyle (in litt.; Pyle 1997), from the white median coverts of the formative plumage, it was likely a first-spring Black-backed Wagtail (M. a. lugens. The date can be considered early, given that of the 37 White Wagtails known from California, eight were in spring (18 Apr-22 May), including two from inland locations (Hamilton et al. 2007; www.californiabirds.org/cbrc_book/update.pdf).

PURPLE FINCH Haemorhous purpureus $(4,6,22)$. The status of the Purple Finch in Arizona has changed in recent years, with no fewer than 22 accepted records for this report. These are of one at Lake Havasu City, MOH, 25 Jan-29 Mar 2015 (†, ph. DVP); another there 19 Oct-1 Nov 2015 (ph. DVP); one at South Dike, Havasu NWR, MOH, 26 Oct 2015 (†LHa), one at Ajo, PIM, 25 Oct-24 Nov 2015 


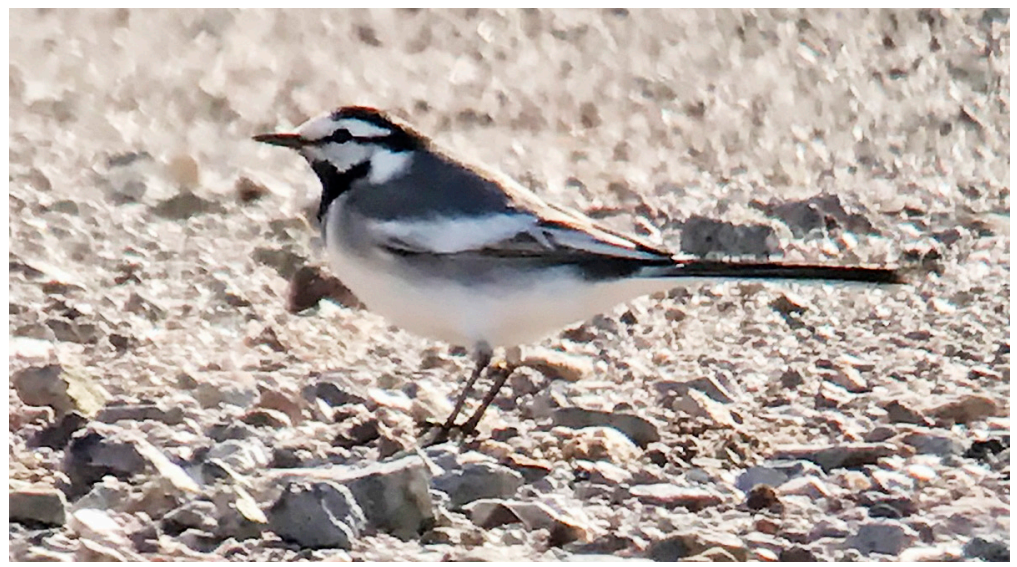

Figure 11. White Wagtail at Ajo, Pima Co., 29 Mar-1 Apr 2017, representing a second record for Arizona.

Photo by Chris McCreedy

(†, ph. CMc); one at Morgan City Wash near Lake Pleasant, MAR, 14 Nov 2015 (ph. JMo); one in Maricopa, PIN, 26 Nov 2015 (†, ph. NL), three at Gilbert Water Ranch, MAR, 30 Nov 2015-27 Jan 2016 (†, ph. TL); five to seven at Aspen Creek, YAV, 2-12 Dec 2015 (ph. BP); one along Tanque Verde Wash e. of Tucson, PIM, 15 Dec 2015 (†, ph. PS); one at Seven Springs near Cave Creek, MAR, 4 Jan 2016 (†, ph. BI); one along Skunk Creek, Peoria, MAR, 5-10 Jan 2016 (†, ph. TD); up to five along Gillespie Wash near Safford, GRA, 9-10 Jan 2016 (†, ph. JCk); two at Arivaca Cienega, Buenos Aires NWR, PIM, 18 Jan 2016 (†DG), with another (possibly one of the same) 5 Mar 2016 (†DG); seven along Hwy. 87 ne. of Fountain Hills, MAR, 21-31 Jan 2016 ( $\dagger$, ph. SF); one in Ash Canyon, COS, 28-29 Feb 2016 (†, ph. J\&DP); one at El Rio Open Space Preserve in Marana, PIM, 27 Apr 2016 ( $\dagger$, ph. AC); one at Portal, COS, 14 May 2016 (†DS); four along Aspen Creek near Prescott, YAV, 18-30 Nov 2016 ( $†$, ph. TC); one at Pintail Slough, Havasu NWR, MOH, 30 Oct 2017 (†DVP, EH); five at Rotary Park, Lake Havasu City, MOH, 5 Nov 2017 (†LHa); and a different individual there 9-17 Nov 2017 (†, ph. DVP, LHa). All of the above records are believed to be of the western subspecies californicus. The frequency of Purple Finch reports in Arizona, as well as other states in the Southwest, including Nevada (Tinsman and Meyers 2019), has increased in recent years. At the end of 2017 the $\mathrm{ABC}$ discontinued reviewing reports of $H$. p. californicus but continues to solicit any reports of the more eastern H. p. purpureus, for which there is one accepted Arizona record (Phillips et al. 1964).

WHITE-WINGED CROSSBILL Loxia leucoptera (0, 1, 1). Arizona's second accepted record was of two individuals in the Chuska Mts., APA, 10 Dec 2017 (ph. FG); the combination of marginal photos and recordings of the calls eliminated the Red Crossbill, which rarely shows rather bold white wing bars.

LITTLE BUNTING Emberiza pusilla (0, 0, 1). Arizona's first record of this Asian species at Slaughter Ranch, COS, 27 May 2017 ( $†$, ph. REW; Figure 12) was exceptional. All four Little Buntings recorded in California were discovered between 27 Sep and 12 Dec (Hamilton et al. 2007; www.californiabirds.org/cbrc_book/ update.pdf). There is also an 8 Oct 2008 record from Baja California Sur, Mexico (Radamaker and Powell 2010). 


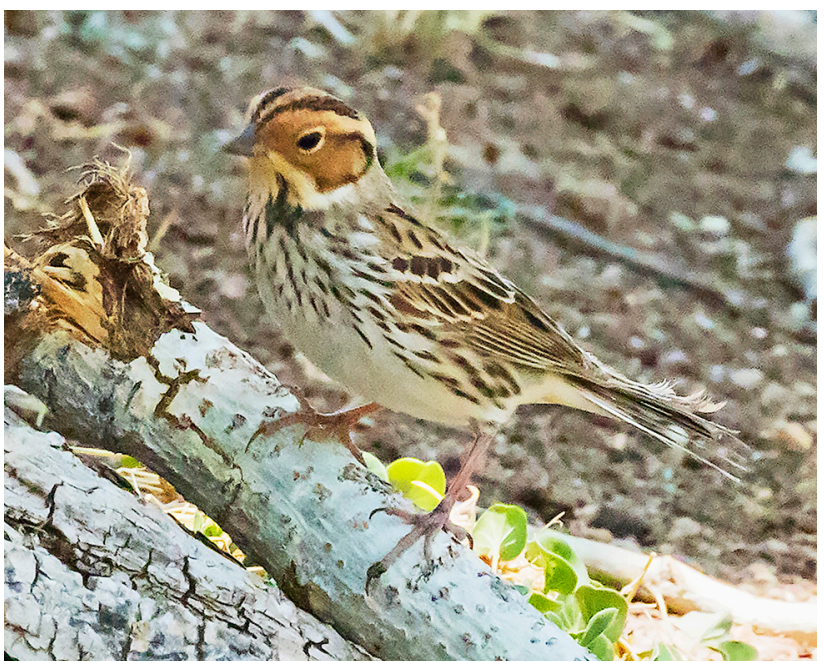

Figure 12. Arizona's first recorded Little Bunting at Slaughter Ranch, Cochise Co., 27 May 2017.

Photo by Richard E. Webster

AMERICAN TREE SPARROW Spizelloides arborea $(\#, 6,1)$. This species remains a casual and irregular winter visitor to Arizona, with most occurrences above the Mogollon Rim in the northern portion of the state. Only one report was evaluated and accepted during this period, of one at Lee's Ferry, COC, 10 Nov 2017 (ph. JWi).

LECONTE'S SPARROW Ammodramus leconteii $(0,2,1)$. One at Dove Mountain 10 km ene. of Marana, PIM, 26-27 Sep 2017 (ph. JHd; ph. CMc, KM, LH, AC; Figure 13) established only the third Arizona record.

BOBOLINK Dolichonyx oryzivorus $(\#, 13,8)$. Accepted records are of an adult

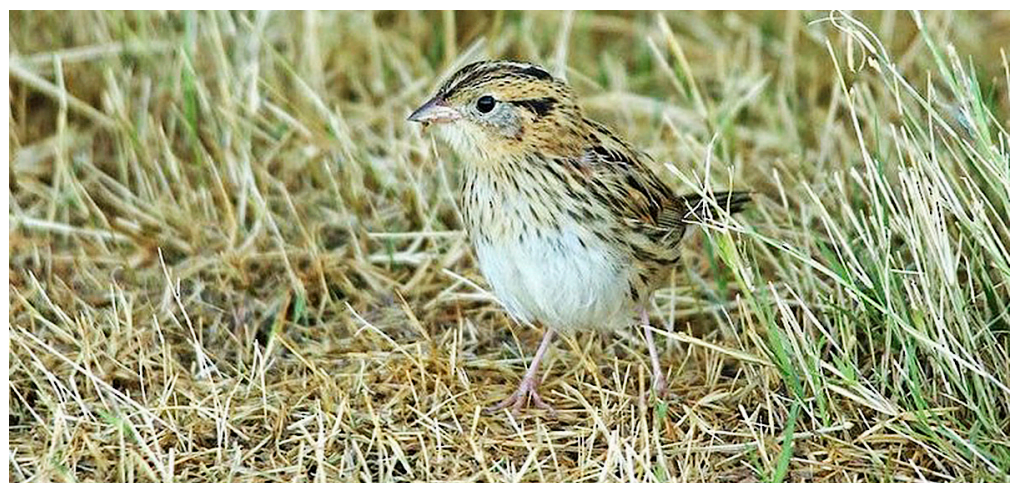

Figure 13. LeConte's Sparrow at Dove Mountain, $10 \mathrm{~km}$ east-northeast of Marana, Pima Co., 26-27 Sep 2017, representing only a third Arizona record.

Photo by Ken Murphy 
male at the Sweetwater Wetlands, PIM, 20 May 2015 (†MMS); one at Gilbert Water Ranch, MAR, 16 Sep 2015 ( $\dagger$, ph. SF); one at the village of Oak Creek, YAV, 28 Oct 2015 (†VN); one male at Page, COC, 14 May 2016 (†, ph. LP); one at Babbitt Tank, COC, 28 Sep 2016 ( $†$, ph. JWi); one at the San Pedro River National Conservation Area, COS, 3 Oct 2016 (ph. JTh); another at Babbitt Tank, COC, 14-18 Oct 2016 (ph. VN); and one at Slaughter Ranch, COS, 28 May 2017 (†, ph. CR). The Bobolink remains a casual spring and fall visitor to Arizona.

STREAK-BACKED ORIOLE Icterus pustulatus (5, 18, 4). A pair was at the Nature Conservancy's preserve along the San Pedro River in Dudleyville, PIN, 18 May-6 Jun 2015 ( $\dagger$, ph. DVP), where a small population persisted during the 1990s (Corman and Wise-Gervais 1990). Elsewhere, one male was at Riverside Park, Yuma, YUM, 24 Dec 2015-26 Mar 2016 (†, ph. JT; ph. HD); one male was at Portal, COS, 12 Nov 2016-2 May 2017 (ph. BR; ph. DW, RS); and a female was at Rio Rico, SCR, 16 May 2017 (†, ph. IM). This species remains a casual visitor to Arizona, although small pockets of resident birds may persist along the lower San Pedro River.

RUSTY BLACKBIRD Euphagus carolinus (9, 22, 4). Accepted records are of one female at Coon Bluff Campground along the Salt River, MAR, 6 Dec 2015-17 Mar 2016 ( $\dagger$, ph. CDB, CR, TD); one female at Willow Tank near Portal, COS, 19 Dec 2015-5 Jan 2016 ( $†$, ph. DJ); one male at the Kachina Wetlands Preserve s. of Flagstaff, COC, 10-17 Nov 2017 ( $\dagger$, ph. TH); and one female at Prescott Valley, YAV, 19 Nov 2017 (†, ph. RB). Although there are more than 30 records from Arizona, the $\mathrm{ABC}$ has retained this species on the review list because it is still casual in the state, and it is still an identification challenge with respect to the more common Brewer's Blackbird (E. cyanocephalus).

COMMON GRACKLE Quiscalus quiscula $(0,33,5)$. Accepted records are of one at Page, COC, 29 Jan 2015 (ph. GN); one at Taylor, NAV, 30 Mar 2015 (†NW); one at Arlington, MAR, 11 Nov 2015 (ph. CS); one at Willcox, COS, 15 Apr 2016 $(\dagger$, ph. M\&LJ); and one at Meteor Crater $60 \mathrm{~km}$ e. of Flagstaff, COC, 18 Oct-2 Nov 2017 (CL, JC; ph. JWi). As with the Rusty Blackbird, there are now more than 30 records for Arizona, the minimum for removal from the $\mathrm{ABC}$ 's review list, but the committee still considers this species casual in Arizona and potentially confused with both Brewer's Blackbird and the Great-tailed Grackle.

GOLDEN-WINGED WARBLER Vermivora chrysoptera (1, 20, 5). Five Goldenwinged Warblers were accepted for this report: one in Miller Canyon, COS, 19 Aug 2015 (†JVR); one at Sheep's Crossing in the White Mountains, APA, 3 Sep 2015 (ph. NP, PBa); one in the Bradshaw Mountains along the Hassayampa River, YAV, 23 Sep 2015 ( $†$, ph. DM); one in Madera Canyon, SCR, 1 Jun 2016 (†, ph. KKu); and one at the Shores Recreation Site along the Gila River, GIL, 19 May 2017 ( $\dagger$, ph. TD). This species remains casual in Arizona in both spring and fall.

BLUE-WINGED WARBLER Vermivora pinus (1, 13, 3). Accepted records are of one in Whitetail Canyon, Chiricahua Mts., COS, 14 Sep 2015 (†RT); one in Prescott, YAV, 25 Sep 2015 (ph. CT); and one in Yuma, YUM, 6 Jun 2016 ( $†$, ph. $\mathrm{SD})$. The Blue-winged Warbler remains casual in Arizona, with about equal numbers of spring and fall records.

CRESCENT-CHESTED WARBLER Oreothlypis superciliosa $(0,14,1)$. One at Granite Basin Lake, YAV, 17 May 2015 (CT; ph. C\&SB) established the first Arizona record north of Madera Canyon in southeastern Arizona.

MOURNING WARBLER Geothlypis philadelphia $(0,8,1)$. An immature at Mormon Lake, COC, 31 Aug 2017 ( $\dagger$, ph. JWi) represented only the ninth accepted record for Arizona.

KENTUCKY WARBLER Geothlypis formosus (3, 33, 1). The only accepted 
record was of one at the Boyce Thompson Arboretum, PIN, 13 Sep 2015 (ph. GM). This species remains casual in Arizona and is particularly infrequent during fall.

BAY-BREASTED WARBLER Setophaga castanea (0, 19, 2). Two accepted records, of one in Yuma, YUM, 6-7 Nov 2016 (ph. MV, HD) and one at Lonely Dell Ranch, Glen Canyon NRA, COC, 9-12 Nov 2017 (ph. RM).

BLACKBURNIAN WARBLER Setophaga fusca $(0,22,2)$. Accepted records are of one along Diamond Creek near Whiteriver, NAV, 18 Sep 2015 ( $\dagger$, ph. EH), and one at Gilbert Water Ranch, MAR, 28 Oct 2017 (†, ph. TD).

BLACKPOLL WARBLER Setophaga striata $(4,26,4)$. Accepted records are of one at Gilbert, MAR, 15 Sep 2016 (ph. DC; ph. CMc, SV); a male at the Sweetwater Wetlands, Tucson, PIM, 7-9 May 2017 ( $\dagger$, ph. CR); one at the Glendale recharge pond, Glendale, MAR, 1 Sep 2017 ( $\dagger$, ph. TD); and one again at the Sweetwater Wetlands, PIM, 16 Dec 2017 (ph. MWe, SVo), providing one of the latest fall records for Arizona.

PINE WARBLER Setophaga pinus (0, 21, 6). Six records accepted, with one at Sonoita, PIM, 5 Dec 2015 (ph. KC); one at the Randolph Golf Course, Tucson, PIM 14-20 Dec 2015 (WR; †MMS); one in Sunnyside Canyon, SCR, 29 Dec 2015 (†KB); one at McCormick Ranch, Scottsdale, MAR, 30 Oct 2016 (†WT); one at Saint David, COS, 21-22 Nov 2017 (ph. AR), and one along the Salt River east of Phoenix, MAR, 14-20 Dec 2017 (ph. MVW). Virtually all of the Arizona records are from late fall or winter.

YELLOW-THROATED WARBLER Setophaga dominica (0, 32, 5). Accepted records are of one at Saint David, COS, 5 Nov 2015 ( $\dagger$, ph. BJ); one at Patagonia, SCR, 6 Dec 2015-12 Mar 2016, perhaps returning after having wintered there the previous year (ph. DWi); one at the Tres Rios Wetlands, Phoenix, MAR, 9-24 Dec 2015 (ph. CS); one in Ash Canyon, COS, 17 May 2016 (ph. RBe); and one again in Patagonia, SCR, 7-27 Feb 2017 (ph. MWe, DSu). As there are more than 30 Arizona records, occurrence is almost annual, and the species is distinctive, the $\mathrm{ABC}$ removed this species from its review list at the end of 2017.

PRAIRIE WARBLER Setophaga discolor $(3,14,1)$. One was at Gilbert Water Ranch, MAR, 25-30 Oct 2017 ( $\dagger$, ph. J\&CG).

BLACK-THROATED GREEN WARBLER Setophaga virens $(7,24,3)$. Two records were accepted from the Hassayampa River Preserve near Wickenburg, MAR, of one 24-25 Dec 2016 (ph. CL) and one on 16 Apr 2017 (ph. J\&DB; ph. CKS). Elsewhere, one was along Sasco Road near Marana, PIN, 16-18 Jan 2017 (ph. LH). Although there are now more than 30 records from Arizona, the ABC has decided to retain this species on its review list.

FAN-TAILED WARBLER Basileuterus lachrymosus (1, 8, 1). Arizona's tenth Fan-tailed Warbler was netted and banded in Ramsey Canyon, COS, 31 May 2015 (ph. WL).

RUFOUS-CAPPED WARBLER Basileuterus rufifrons $(0,26,8)$. The number of localities where the Rufous-capped Warbler has occurred in Arizona continues to increase. Accepted records for this report are of one at Peña Blanca Lake, SCR, 13 Jan-25 Feb 2015 (ph. PS), apparently the same individual there 30 Dec 2015-25 Mar 2016, and two in Hunter Canyon, Huachuca Mts., COS, 13 Mar 2015, with an apparent family group of five there 23 Sep 2015 (†, ph. AM; ph. IS; ph. JVR). From then this species was reported there nearly continuously through $19 \mathrm{Dec} 2017$. A family group of five was found in Peña Blanca Canyon, SCR, 10 Jul 2015 (ph. LH), after which sporadic reports continued through 6 Nov 2016. Elsewhere, one was at the Peña Blanca Lake dam, SCR, 27 Aug 2015 (ph. CMc) and 27 Apr-11 May 
2016; one was reported sporadically in Miller Canyon, COS, 29 Sep 2015-14 Nov 2017 (†JMi); one was in Ventana Canyon, Santa Catalina Mts., PIM, 21 Nov-19 Dec 2015 (ph. PS); one was at Tonto Canyon w. of Rio Rico, SCR, 30 Dec 2016 (†CC); one was about $2 \mathrm{~km} \mathrm{w}$. of Rock Corral, SCR, 2 Jan 2017 (ph. SF); and a population has persisted in Florida Canyon, PIM, throughout the period covered by this report. As the Rufous-capped Warbler has increased steadily in southeastern Arizona in recent years, and the total number of records in the state now exceeds 30 , the $A B C$ removed it from the review list at the end of 2017.

SLATE-THROATED REDSTART Myioborus miniatus (0, 13, 3). Accepted records are of one at the Hirabayashi Rest Area on Mount Lemmon, PIM, 19-20 Mar 2015 (ph. PS; ph. KM, JH, JS, MV); one in Hunter Canyon, COS, 25 Jul-12 Oct 2015 (RR, GS; †MBr; ph. BA); and one female in Pinery Canyon, COS, 3 May-21 Jul 2016. The last evidently mated with a male Painted Redstart, as it was seen feeding what was considered a hybrid young Painted Redstart $\times$ Slate-throated Redstart 19 Jun 2016 (ph. ASt; ph. JL, AR, GE, JB, SWo, PBa, SS). This individual returned to the same location in Pinery Canyon 30 Apr-24 Jun 2017 (ph. TJ, MW) and again was likely mated with a Painted Redstart. The frequency of the Slate-throated Redstart in Arizona has been increasing in recent years.

SCARLET TANAGER Piranga olivacea $(4,30,1)$. One accepted record, of one at Spring Creek Ranch near Sedona, YAV, 22 Oct 2017 (ph. TC). As there are now more than 30 Arizona records the $\mathrm{ABC}$ removed the Scarlet Tanager from its review list at the end of 2017.

FLAME-COLORED TANAGER Piranga bidentata $(0,18,3)$. The status of this species in the Huachuca Mountains remains uncertain. Accepted records are of a pair in lower Ramsey Canyon (Bledsoe Loop), COS, 14 May-9 Aug 2015 (ph. MSc); of a presumed different male in upper Ramsey Canyon, COS, 4 Jun-7 Aug 2015 (ph. DVP); at least a male again in lower Ramsey Canyon, COS, 13 Mar-26 May 2016 (ph. AR, CDB, BBr); and a male in Garden Canyon, COS, 7-11 May 2017 (ph. ER, JA). A pair apparently remained in upper Ramsey Canyon all summer during 2017, yet documentation was never submitted to the $\mathrm{ABC}$.

\section{REPORTS NOT ACCEPTED}

FULVOUS WHISTLING-DUCK Dendrocygna bicolor. A report of one heard only and identified later at Gilbert Water Ranch, Gilbert, MAR, 1 Nov 2017 received no support from the committee.

TRUMPETER SWAN Cygnus buccinator. The ABC believes the report of two supposed immature Trumpeter Swans from Whitewater Draw, COS, 15 Jan 2015 to represent the same two Tundra Swans (C. columbianus) reported at that location 10-15 Jan 2015. Though two immature swans at Tres Rios, MAR, 19 Dec 2016 had legs described as "beige/yellow/blackish and more yellow at the base of their legs," other features, such as overall color, shape, and bill color were better for the Tundra Swan and the record was not accepted. The report of one immature from the north end of Lake Havasu, MOH, 5 Dec 2016, was not detailed enough to accept. Identification of immature swans is notoriously difficult (Armistead and Sullivan 2016).

BLACK SCOTER Melanitta nigra. The report of one in the Bill Williams arm of Lake Havasu, LAP, 31 Mar 2016 was not detailed enough for acceptance, while a description of three in the same area on 30 Dec 2016 was inconsistent with the claimed species; several committee members suggested the birds were Surf Scoters (M. perspicillata) known to be present at the location.

LEAST GREBE Tachybaptus dominicus. A report of one in the Bill Williams 
arm of Lake Havasu, LAP, 7 Jan 2017 received no support, with a majority of the committee believing the description better fit an Eared Grebe (Podiceps nigricollis).

RUBY-THROATED HUMMINGBIRD Archilochus colubris. A submitted photo of a supposed Ruby-throated Hummingbird in Mesa, MAR, 1 Oct 2015 showed a female Anna's Hummingbird (Calypte anna), and a report of one in Scottsdale, MAR, 1 Jun 2016 received no support from the committee.

AMERICAN GOLDEN-PLOVER Pluvialis dominica. A report of one from Cibola NWR, LAP, 3-4 Mar 2015 was found to represent a Black-bellied Plover $(P$. squatarola) and was later retracted by the observer. One reported by an observer playing golf in Prescott, YAV, 25 Apr 2017 received no support from the committee.

LAUGHING GULL Leucophaeus atricilla. A written description of one at Mormon Lake, COC, 7 May 2017 did not definitively rule out a Franklin's Gull (L. pipixcan).

LEACH'S/TOWNSEND'S STORM-PETREL (Oceanodroma leucorhoa/socorroensis). The report of one from the Amado sewage-treatment pond, PIM, 7 Sep 2016 was later retracted and accepted as representing a Wedge-rumped Storm-Petrel (see accepted records above). Another report in the wake of Hurricane Newton, of one seen while the observer was driving near Tubac, SCR, 7 Sep 2016 was accepted only as an unidentified storm-petrel. Several other reports of unidentified storm-petrels seen during the storm were not submitted to the $\mathrm{ABC}$.

YELLOW-CROWNED NIGHT-HERON Nyctanassa violacea. The report of one near the Sonoita Creek Preserve, SCR, 12 Feb 2014 was not detailed enough for acceptance.

GLOSSY IBIS Plegadis falcinellus. Several reports were not accepted, including a flock of 20+ individuals in Marana, PIM, 23 Sep 2015; an adult at the Yuma East Wetlands, YUM, 23 Apr 2016; a hatch-year bird at the Tres Rios Wetlands, MAR, 2 Jul 2016; an adult at the Green Valley sewage-treatment pond, PIM, 26 Jul 2017; and a hatch-year at Roper Lake State Park, GRA, 3 Oct 2017. The report of the flock at Marana failed to rule out the more expected White-faced Ibis (P. chihi). Both supposed adults showed the red eyes and tinge to the facial skin typical of the Whitefaced Ibis. In their first year these ibises are often indistinguishable, as both can show dark eyes and facial skin (Pyle 2008).

SHORT-TAILED HAWK Buteo brachyurus. Details of reports of Short-tailed Hawks at Summerhaven, PIM, 2 May 2015; at Arivaca, PIM, 1 Sep 2015; near Safford, GRA, 19 Jun 2016; near Sierra Vista, COS, 18 Jul 2017; and at Saint David, COS, 5 Aug 2017 were all insufficient for acceptance, failing to eliminate Swainson's Hawk. The Short-tailed was removed from the ABC's review list at the end of 2017.

APLOMADO FALCON Falco femoralis. A report of one in Oro Valley, PIM, 22 Feb 2016 received no support from the committee.

NUTTING'S FLYCATCHER Myiarchus nuttingi. The identification of one reported in the southern San Simon Valley (southwest of Rodeo, New Mexico), COS, 6 Oct 2015 relied primarily on the lack of dark across the tip of the tail, a feature also of the juvenile plumage of the Ash-throated Flycatcher ( $M$. cinerascens), which the committee agreed the report more likely represented. An intriguing report of a "wheep" call from a presumed Myiarchus in Miller Canyon, COS, 17-19 Jul 2016 was not accepted. Analyses of the recordings found the call intermediate between that of a Nutting's and that of a Great Crested Flycatcher (M. crinitus). Unfortunately, the bird was never seen.

YELLOW-BELLIED FLYCATCHER Empidonax flaviventris. One reported at Granite Reef Recreation Area in Mesa, MAR, 18 Feb 2015 was thought by the 
committee to have been a Gray Flycatcher, while one reported at Patagonia, SCR, 7 Jan 2017 was a Hammond's Flycatcher.

BLUE-HEADED VIREO Vireo solitarius. Photos of vireos identified as this species near Sonoita, PIM, 27 Apr 2015 and at Ramsey Canyon, COS, 7 Nov 2015 were both inconclusive in distinguishing the bird from a bright Cassin's Vireo. One report from Hassayampa has been recirculated.

PHILADELPHIA VIREO Vireo philadelphicus. A photograph of a supposed Philadelphia Vireo submitted from Madera Canyon, PIM, 18 Sep 2015 was thought by all on the committee to show an Orange-crowned Warbler. One written description from Willcox, COS, 2 Sep 2017 suggested a Philadelphia Vireo, but the very early date and common confusion with a bright immature Warbling Vireo (V. gilvus) precluded acceptance.

RED-EYED VIREO Vireo olivaceus. One was briefly described from Madera Canyon, SCR, 3 May 2016, but the report did not rule out a Warbling Vireo.

YELLOW-GREEN VIREO Vireo flavoviridis. The identification of one reported from Montosa Canyon, SCR, 10 Jul 2015 was thought by some on the committee to be likely correct, but a majority of the $\mathrm{ABC}$ agreed that the description did not rule out the similar Red-eyed Vireo.

CAVE SWALLOW Petrochelidon fulva. A report of one heard and seen only without the aid of optics in Liberty, MAR, 30 Oct 2016, lacked enough details for acceptance.

BLACK-CAPPED CHICKADEE Poecile atricapillus. One reported from Williams, COC, 15 Apr 2015 was not described well enough for acceptance, particularly given that the Mountain Chickadee is known to breed at this location.

CAROLINA WREN Thryothorus ludovicianus. The report of one from Arivaca, PIM, 18 Jan 2016 was somewhat controversial: the details appeared to have been generated well after the actual sighting, creating doubt with several committee members.

CLAY-COLORED THRUSH Turdus grayi. From a single photograph, the committee concluded that one in a yard in Portal, COS, 21 Jun 2015 was correctly identified. A majority of the ABC, however, thought the bird had possibly not occurred naturally. This was a difficult decision for several members. The mid-summer date is outside the species' normal period of vagrancy in Texas, and caged individuals are often seen in Mexico, leading the committee to be conservative and not accept this record as a first for Arizona. If additional Clay-colored Thrushes appear in Arizona, it is likely that this record will be re-evaluated.

AZTEC THRUSH Ridgwayia pinicola. One reported from urban Phoenix, MAR, 27 Apr 2016 was described only briefly, and the committee concluded it was likely a juvenile of some other species with white spotting.

PURPLE FINCH Haemorhous purpureus. The photograph of a reported Purple Finch at Patagonia, SCR, 25 Jan 2015 shows a bright male House Finch, and one of a female-plumaged finch at the Sweetwater Wetlands, Tucson, PIM, 10 Jan 2016 more likely shows a female House Finch.

COMMON GRACKLE Quiscalus quiscula. The committee believes the photos of a reported Common Grackle at Prescott, YAV, 14 Oct 2015 represent a Brewer's Blackbird.

GOLDEN-WINGED WARBLER Vermivora chrysoptera. A photo supposedly of this species at Glendale, MAR, 25 Feb 2016 showed a Verdin (Auriparus flaviceps).

CONNECTICUT WARBLER Oporornis agilis. Details of one reported at Patagonia, SCR, 25 Sep 2016 were insufficient for acceptance of a second state record. 
MOURNING WARBLER Oporornis philadelphia. An odd individual showing very little white around the eye at Agua Caliente Park, Tucson, PIM, 26 May 2016 was thought by the committee to be either an aberrant MacGillivray's Warbler or a hybrid. An "immature" reported at Benson on $27 \mathrm{Jul} 2016$ was well described, but as the date was unprecedented for this plumage a majority of the committee could not accept it.

KENTUCKY WARBLER Oporornis formosus. The report of one at Holbrook, NAV, 26 Sep 2015 had details insufficient for acceptance.

PINE WARBLER Dendroica pinus. One described from McCormick Ranch, Scottsdale, MAR, 3 Oct 2015 had details insufficient to definitively eliminate confusing similar species.

RUFOUS-CAPPED WARBLER Basileuterus rufifrons. Two reports of this species were not accepted because of insufficient details, of one near Amado, SCR, 15 Mar 2015 and one near Ruby, SCR, 26 Jan 2017.

FLAME-COLORED TANAGER Piranga bidentata. A male reported as this species in upper Miller Canyon, COS, 5 May 2015 appeared to be a hybrid.

\section{ACKNOWLEDGMENTS}

We thank the more than 187 observers who submitted material to the AZFO and $\mathrm{ABC}$; they have made an important contribution to our expanding knowledge of the status of Arizona birds. Thanks to Steve Mlodinow for comments on the report of the Trumpeter Swan from Tres Rios. Thanks to reviewers Chris McCreedy and Ryan Terrill, who both contributed greatly to the improvement of the manuscript. Philip Unitt also improved the manuscript.

\section{CONTRIBUTORS}

Jesse Amesbury, Walt Anderson, Bettina Arrigoni, Charles Babbitt (CBa), Doug Backlund, Richard Balland, Tony Battiste (TBa), Pam Baum (PBa), Pete Baum, Matt Baumann ( $\mathrm{MBa})$, Robert Behrstock (RBe), Chris D. Benesh, Tom Benson, Bruce Berman (BBe), Jim Berry, Laurie Betchler (LBe), Ken Blankenship, Owen Bobier, Jaculin Bowman, Steve Boyack, Dennis Braddy, Matt Brady (MBr), Bill Brown (BBr), Duncan Brown (DBr), Matt Brown, Babs Buck, Roberta and David Chorlton, Dale Clark, Jeff Coker (JCk), John Coons, Michael Cooper, Andrew Core, Troy Corman, Charles Corson, Joe Crouse (JCr), Katherine Cudney, Tommy DeBardeleben, Henry Detwiler, Suzanne Detwiler, Richard Ditch, J. Duerr, Reba and Allan Dupika, Gil Ewing, Craig Fischer, Sean Fitzgerald, Brenden Gebhart (BGe), Reinhard Geisler, Cris Gentis, Brian Gibbons (BGi), Pat Goltz, Brendon Grice, David Griffin, John Groves, Felipe Guerrero, Laurens Halsey, Ed Harper, Ned Harris, Lauren Harter (LHa), Jennifer Hayduk (JHd), James Hays, Thomas Hedwall, Melanie Herring, Bill Higgins, John Higgins (LHi), Louis Hoeniger (LHo), Tonya Holland, Steve Hosner, Eric Hough (EHo), Bernard Howe, Brian Ison, Jerry Jackson, Marty Jakle, Max \& Lynn Jarrett, Doug Jenness, Brian Johnson, Tom Johnson, Glenda Jones, Gary Jue, Keith Kamper, Gordon Karre, Glenn Klingler (GKl), Chrissy Kondrat-Smith, Margaret Kunes, Kathy Kuyper (KKu), Nancy Lange, Shawn Langston, Theresa Lawson (TLa), Wade Leitner, Tony Leonardini, Michael Lester, Jackie Lewis, Tom Linda (TLi), Bill Lisowsky, Grant Loomis, Tyler Loomis, Carl Lundblad, Mike Margolis (MMa), Aaron Marshall, Janine McCabe (JMb), Inayat McCarthy, Chris McCreedy (CMc), James McKay (JMc), Greg McKee, Mickey McLean, Jeremy Medina (JMe), Charles Melton, Martin Meyers (MMe), Jennifer Miller (JMi), Steve Mlodinow, David Moll, Jason Morgan (JMo), Roy Morris, Duane Morse, Valerie Motyka, Brad Murphy, Ken Murphy, Gerry Nealon, Vic Nelson, Brian Nicholas, Larry Norris, Scott Olmstead, Jim \& Debby Parker, Bryan Patrick, Jan Parrott, Nan Perkins, Mark Phillips, Lonnie Pilkington, Larry Pratt 
(LPr), Kurt Radamaker, Deborah Rasmussen, Edward Raynor, James V. Remsen, Matthew Reynolds, Arlene Ripley, Jim Ripley, Jeff Ritz (JRi), Bob Rodrigues, Chris Rohrer, Rick Romae, Gary H. Rosenberg, Isaac Sanchez, Mike Schackwitz (MSc), Alan Schmierer, Bill Scott, Glen Seeholzer, Robert Shantz, Shannon Skalos, Jerome Smith, Bob Steele, David J. Stejskal, Andy Stepniewski (ASt), Mark M. Stevenson, Caleb Strand, Paul Suchanek, Donald Sutherland (DSu), Cheyenne Szydlo (CSz), Jay Taylor, Rick Taylor, Jens Thalund (JTh), Craig Thayer (CTh), Walter Thurber, Carl Tomoff, Charles Trapani (CTr), Christie Van Cleve, David Vander Pluym, Steve Valasek, Marceline Vanderwater, Joe Veverka, Matt Victoria, Susan Voelker (SVo), Dennis Wall, Richard E. Webster, Dan Weisz, Michael Welch (MWe), Jennifer Werrell (JWe), Dennis Widman (DWi), Jason Wilder (JWi), John Williams, Melissa Williams, Sheri Williamson, Steve Wolfe (SWo), Michael Woodruff, John Workman (JWo), Nick Worth, John Yerger, Barry Zimmer.

\section{LITERATURE CITED}

Archibald, G.W., Meine, C. D., Garcia, E. F. J., and Kirwan, G. M. 2018. Common Crane (Grus grus), in Handbook of the Birds of the World Alive (J. del Hoyo, A. Elliott, J. Sargatal, D. A. Christie, and E. de Juana, eds.). Lynx Edicions, Barcelona; www.hbw.com/node/53560 (7 Nov 2018).

Armistead, G. L., and Sullivan, B. L. 2016. Better Birding: Tips, Tools, and Concepts for the Field. Princeton Univ. Press, Princeton, NJ; doi 10.1515/9781400874163.

Chesser, R. T., Burns, K. J., Cicero, C., Dunn, J. L., Kratter, A. W., Lovette, I. J., Rasmussen, P. C., Remsen, J. V., Jr., Rising, J. D., Stotz, D. F, and Winker, K. 2017. Fifty-eighth supplement to the American Ornithological Society's Checklist of North American Birds. Auk 134:751-773; doi 10.1642/AUK-17-72.1.

Corman, T. E., and Wise-Gervais, C. 2005. Arizona Breeding Bird Atlas. Univ. of New Mexico Press, Albuquerque.

Erickson, R. A., Hamilton, R. A., Carmona, R., and Ruiz-Campos, G. 2006. Baja California Peninsula region (fall 2005). N. Am. Birds 60:143-146.

Garner, M., Lewington, I., and Slack, R. 2003. Mongolian and Lesser Sand Plovers: An identification overview. Birding World 16:377-385.

Hamilton, R. A. 2008. Fulvous Whistling-Duck (Dendrocygna bicolor), in California bird species of special concern: A ranked assessment of species, subspecies, and distinct populations of birds of immediate conservation concern in California (W. D. Shuford and T. Gardali, eds.), pp. 68-73. Studies in Western Birds 1. W. Field Ornithol., Camarillo, CA, and Calif. Dept. Fish and Game, Sacramento.

Hamilton, R. A., Patten, M. A., and Erickson, R. A. (eds.). 2007. Rare Birds of California. W. Field Ornithol., Camarillo, CA.

Howell, S. N. G. 2012. Petrels, Albatrosses, and Storm-Petrels of North America: A Photographic Guide. Princeton Univ. Press, Princeton, NJ; doi $10.1515 / 9781400839629$.

Howell, S. N. G., Lewington, I., and Russell, W. 2014. Rare Birds of North America. Princeton Univ. Press. Princeton, NJ; doi 10.1515/9781400848072.

Jones, R. M. 1999. Seabirds carried inland by tropical storm Nora. W. Birds 30:185-192.

Kammerichs-Berke, D. 2018. Northernmost record of the Wedge-rumped StormPetrel (Oceanodroma tethys). W. Birds 49:74-76; doi 10.21199/WB49.1.5.

Meyers, M. 2015. Nevada Bird Records Committee report for 2013. W. Birds 46:8-27.

Monson, G., and Phillips, A. R. 1981. Annotated Checklist of the Birds of Arizona, 2nd ed. Univ. of Ariz. Press, Tucson.

Nelson, K. N., Rottenborn, S. C., and Terrill, S. B. 2013. The 37th report of the California Bird Records Committee: 2011 records. W. Birds 44:206-236 
Patten, M. A., McCaskie, G., and Unitt, P. 2003. Birds of the Salton Sea. Univ. of Calif. Press, Berkeley.

Phillips, A. R., Monson, G., and Marshall, J. 1964. The Birds of Arizona. Univ. of Ariz. Press, Tucson.

Pike, J. E., Garrett, K. L., and Searcy, A. J. 2014. The 38th annual report of the California Bird Records Committee: 2012 records. W. Birds 45:246-275.

Pyle, P. 1997. Identification Guide to North American Birds, part 1. Slate Creek Press, Bolinas, CA.

Pyle, P. 2008. Identification Guide to North American Birds, part 2: Anatidae to Alcidae. Slate Creek Press, Point Reyes Station, CA.

Radamaker, K. A., and Powell, D. J. 2010. A Little Bunting reaches Baja California Sur. W. Birds 41:55-58.

Rosenberg, G. H. 2001. Arizona Bird Committee Report: 1996-1999 records. W. Birds 32:50-70.

Rosenberg, G. H., and Witzeman, J. L. 1998. Arizona Bird Committee report, 1974-1996: Part 1 (non-passerines). W. Birds 29:199-224.

Rosenberg, G. H., and Witzeman, J. L. 1999. Arizona Bird Committee report, 1974-1996: Part 2 (passerines). W. Birds 30:94-120.

Rosenberg, G. H., Radamaker, K., and Stevenson, M. 2007. Arizona Bird Committee report, 2000-2004 records. W. Birds 38:74-101.

Rosenberg, G. H., Radamaker, K., and Stevenson, M. 2011. Arizona Bird Committee report, 2005-2009 records. W. Birds 42:198-232.

Rosenberg, G. H., Radamaker, K., and Vander Pluym, D. 2017. Arizona Bird Committee report, 2011-2015 records. W. Birds 48:74-112; doi 10.21199/ WB48.2.1.

Rosenberg, G. H., and Stejskal, D. J. 2018. First record of the Pine Flycatcher (Empidonax affinis) for Arizona and the United States. W. Birds 49:289-292; doi 10.21199/WB48.4.7.

Shoch, D. T., and Howell, S. N. G. 2013. Occurrence and identification of vagrant "orange-billed terns" in eastern North America. N. Am. Birds 67:188-209.

Speich, S., and Parker, T. A. 1973. Arizona bird records, 1972. W. Birds 4:53-57.

Speich, S. M., and Witzeman, J. L. 1975. Arizona bird records, 1973, with additional notes. W. Birds 6:145-155.

Sullivan, B. L., Iliff, M. J., Ralph, P. L., Ralph, C. J., and Kelling, S. T. 2007. A Lesser Frigatebird (Fregata ariel) in California: A first for the state and fourth for North America. N. Am. Birds 61:540-545.

Tinsman, J., and Meyers, M., 2019. Nevada Bird Records Committee report for 2017. W. Birds 50:2-15; doi 10.21199/WB50.1.1.

Unitt, P. 1984. The birds of San Diego County. San Diego Soc. Nat. Hist. Memoir 13.

Velarde, E., and Rojo, P. 2012. Presumed hybrid Elegant $\times$ Cabot's Terns Thalasseus elegans $\times$ T. acuflavida in Isla Rasa, Gulf of California, Mexico. Marine Ornithol. 40:25-29. 